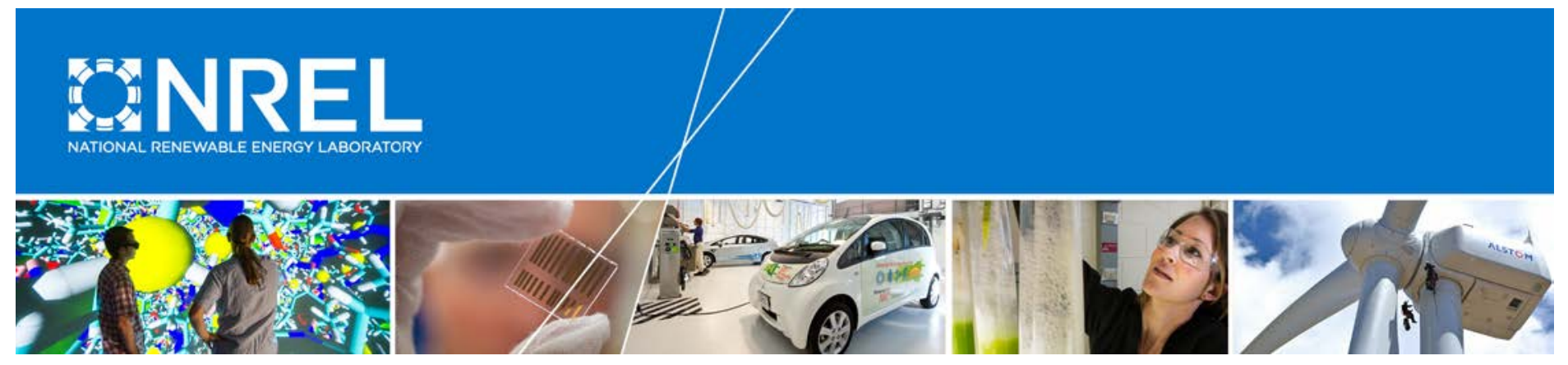

\title{
Biogas and Hydrogen Systems Market Assessment
}

Anelia Milbrandt, Brian Bush, and Marc Melaina National Renewable Energy Laboratory (NREL)

NREL is a national laboratory of the U.S. Department of Energy Office of Energy Efficiency \& Renewable Energy Operated by the Alliance for Sustainable Energy, LLC

This report is available at no cost from the National Renewable Energy Laboratory (NREL) at www.nrel.gov/publications.

Technical Report

NREL/TP-6A20-63596

March 2016

Contract No. DE-AC36-08G028308 


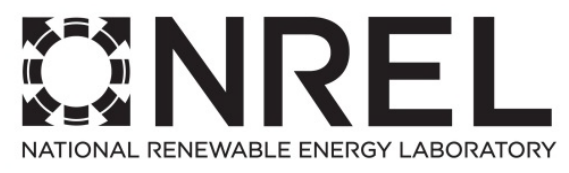

\title{
Biogas and Hydrogen Systems Market Assessment
}

\author{
Anelia Milbrandt, Brian Bush, and Marc \\ Melaina \\ National Renewable Energy Laboratory (NREL) \\ Prepared under Task No. HT12.2A10
}

NREL is a national laboratory of the U.S. Department of Energy Office of Energy Efficiency \& Renewable Energy Operated by the Alliance for Sustainable Energy, LLC

This report is available at no cost from the National Renewable Energy Laboratory (NREL) at www.nrel.gov/publications.

National Renewable Energy Laboratory 15013 Denver West Parkway Golden, CO 80401

303-275-3000 • www.nrel.gov
Technical Report

NREL/TP-6A20-63596

March 2016

Contract No. DE-AC36-08G028308 


\section{NOTICE}

This report was prepared as an account of work sponsored by an agency of the United States government. Neither the United States government nor any agency thereof, nor any of their employees, makes any warranty, express or implied, or assumes any legal liability or responsibility for the accuracy, completeness, or usefulness of any information, apparatus, product, or process disclosed, or represents that its use would not infringe privately owned rights. Reference herein to any specific commercial product, process, or service by trade name, trademark, manufacturer, or otherwise does not necessarily constitute or imply its endorsement, recommendation, or favoring by the United States government or any agency thereof. The views and opinions of authors expressed herein do not necessarily state or reflect those of the United States government or any agency thereof.

This report is available at no cost from the National Renewable Energy Laboratory (NREL) at www.nrel.gov/publications.

Available electronically at SciTech Connect http:/www.osti.gov/scitech

Available for a processing fee to U.S. Department of Energy and its contractors, in paper, from:

U.S. Department of Energy

Office of Scientific and Technical Information

P.O. Box 62

Oak Ridge, TN 37831-0062

OSTI http://www.osti.gov

Phone: 865.576.8401

Fax: 865.576.5728

Email: reports@osti.gov

Available for sale to the public, in paper, from:

U.S. Department of Commerce

National Technical Information Service

5301 Shawnee Road

Alexandria, VA 22312

NTIS http://www.ntis.gov

Phone: 800.553 .6847 or 703.605 .6000

Fax: 703.605.6900

Email: orders@ntis.gov 


\section{Acknowledgments}

Funding for this report was provided by the U.S. Department of Energy's Fuel Cell Technologies Office. The authors would like to specifically thank Fred Joseck, U.S. Department of Energy, for his guidance and support. We would also like to thank Tibor Vegh from the Nicholas Institute for Environmental Policy Solutions at Duke University for sharing detailed data related to biogas production cost; without these data, this analysis would not have been possible. We thank Michael Penev (National Renewable Energy Laboratory), Genevieve Saur (National Renewable Energy Laboratory), Christopher Yang (University of California - Davis), and Sigmund Gronich (Charisma Consulting) for their review and valuable recommendations. 


\section{Abbreviations and Acronyms}

$\begin{array}{ll}\mathrm{AD} & \text { anaerobic digestion } \\ \mathrm{Btu} & \text { British thermal units } \\ \mathrm{CCS} & \text { carbon capture and storage } \\ \mathrm{CH}_{4} & \text { methane } \\ \mathrm{CHHP} & \text { combined heat, hydrogen, and power } \\ \mathrm{CNG} & \text { compressed natural gas } \\ \mathrm{CO}_{2} & \text { carbon dioxide } \\ \mathrm{CSD} & \text { compression, storage, and dispensing } \\ \mathrm{FCEV} & \text { fuel cell electric vehicle } \\ \mathrm{FOG} & \text { fats, oils, and greases } \\ \mathrm{H} 2 & \text { hydrogen } \\ \mathrm{hr} & \text { hour } \\ \mathrm{kg} & \text { kilogram } \\ \mathrm{kWh} & \text { kilowatt-hour } \\ \mathrm{LNG} & \text { liquid natural gas } \\ \mathrm{m}^{3} & \text { cubic meter(s) } \\ \mathrm{MGD} & \text { million gallons per day } \\ \mathrm{mmBtu} & \text { million Btu } \\ \mathrm{MSW} & \text { municipal solid waste } \\ \mathrm{MW} & \text { megawatt } \\ \mathrm{scf} & \text { standard cubic feet } \\ \mathrm{SMR} & \text { steam methane reforming } \\ \mathrm{tFM} & \text { tonne of fresh matter } \\ \text { tonne } & \text { metric ton } \\ \text { WWTP } & \text { wastewater treatment plant } \\ & \end{array}$




\section{Executive Summary}

Biogas, the gaseous product of anaerobic digestion (AD), has been used for electricity generation and heating for many years, but recently, there has been an interest in biogas as a source for renewable hydrogen that can power fuel cell electric vehicles (FCEVs). Hydrogen-powered FCEVs emit no tailpipe emissions other than water, and they are a clean transportation alternative to gasoline vehicles. Producing hydrogen from biomethane (upgraded biogas) provides energy security through the use of domestic sources, reduces demand for fossil fuels, and supports state and local clean energy initiatives.

This analysis provides an overview of the market for biogas-derived hydrogen and its use in transportation applications. It examines the current hydrogen production technologies from biogas, capacity and production, infrastructure, potential and demand, as well as key market areas. It also estimates the production cost of hydrogen from biogas and provides supply curves at national and point source levels.

Despite projected significant hydrogen potential from biogas, its utilization is yet to be fully realized. As of summer 2014, only one demo plant was producing hydrogen from biogas to power fuel cell vehicles. California is emerging as a key area in the biogas-to-hydrogen market. Not only does the state have the highest hydrogen potential from biogas in the United States, but it also has existing infrastructure and favorable policies to support further development of this industry.

Our cost and supply analysis of biogas-to-hydrogen production via steam methane reforming (SMR) indicates that landfills and wastewater treatment plants (WWTPs) dominate the low-cost supply of biogas-derived hydrogen, but that there is an appreciable amount of moderate-cost hydrogen from livestock operations. Tri-generation (the production of electricity, heat, and hydrogen) yields a somewhat smaller hydrogen resource at a somewhat greater cost than SMR. It is expected that as more fuel cells come online, their cost will go down, which will have a positive effect on the economics of tri-generation systems.

Regarding the market potential, our analysis suggests that at $\$ 5 / \mathrm{kg}$ (delivered cost) landfills can provide about 150 million kg of hydrogen per year and WWTPs can provide about 68 million $\mathrm{kg}$ of hydrogen per year. The annual amount of hydrogen that could be delivered at $\$ 10 / \mathrm{kg}$ grows to about 628 million kg from landfills and 326 million kg from WWTPs. To put this potential in perspective, the FCEV Emphasis scenario in a National Academies report (NRC 2013) projects hydrogen demand for FCEVs in 2030 at about 7.3 billion $\mathrm{kg}$ (equal to about $8 \%$ of fuel demand from the future US light duty vehicle fleet in that scenario) thus landfills and WWTPs can provide between $3 \%$ and $13 \%$ of that demand at $\$ 5 / \mathrm{kg}$ and $\$ 10 / \mathrm{kg}$ respectively. Livestock operations can provide additional hydrogen supply, as well as other biogas sources not examined here (e.g. crop residues).

Production costs of hydrogen from biogas are generally comparable with those of other hydrogen production pathways (e.g., natural gas SMR, coal gasification, biomass gasification, and wind electrolysis) in the $\$ 2-6 / \mathrm{kg}$ range. However, once typical delivery costs are added, only biogasderived hydrogen via SMR of less than about 1 million $\mathrm{kg}$ per day is available at that cost. 
Despite the considerable uncertainty associated with the supply curve and production cost estimates, this study serves as a general reference and a placeholder until a more comprehensive study with much greater detail is completed. Future work could focus on the market potential for other biogas sources not included here (e.g. crop residues) or examine the biogas-to-hydrogen market potential in select regions to obtain detailed resource and cost data that could support indepth feasibility studies. 


\section{Table of Contents}

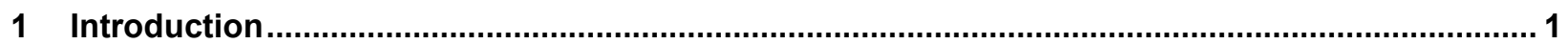

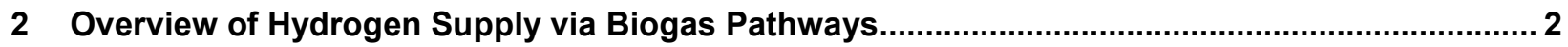

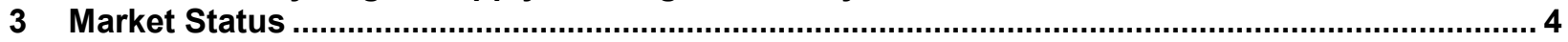

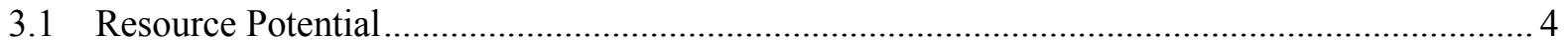

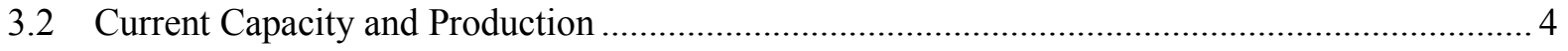

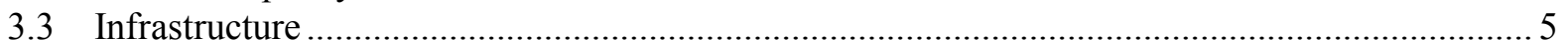

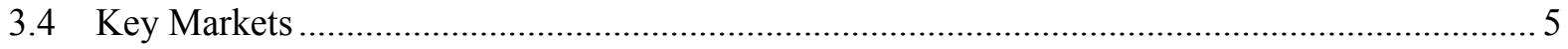

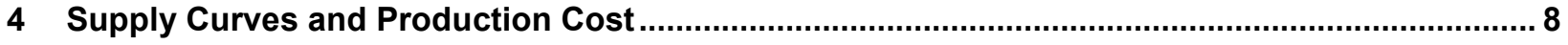

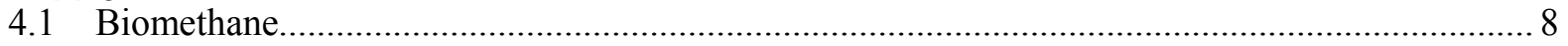

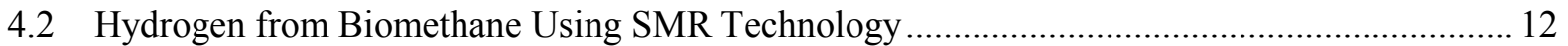

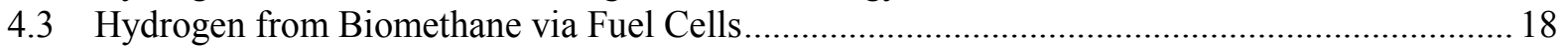

4.4 Combined National Supply Curves for Hydrogen from Biomethane ...................................... 23

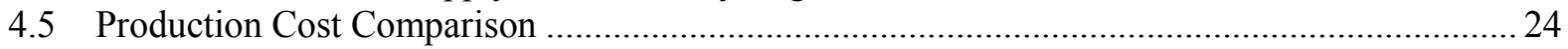

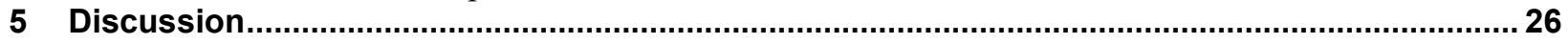

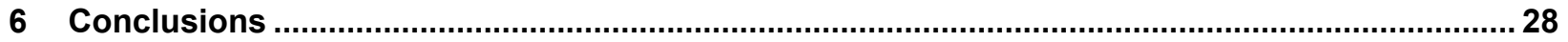

\section{List of Tables}

Table 1. Examples of Biogas-powered Fuel Cell Projects ..................................................................5

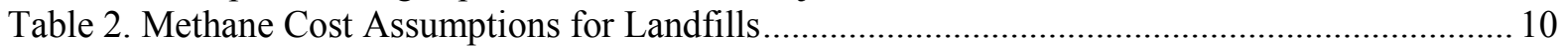

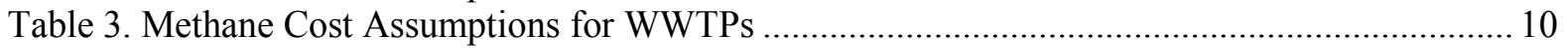

Table 4. Methane Cost Assumptions for Livestock Operations ....................................................... 10

Table 5. Cost Assumptions for Hydrogen Production from Methane via SMR.................................. 13

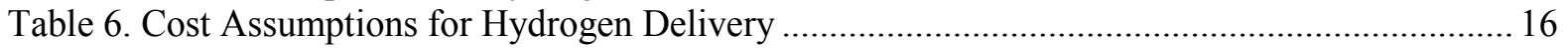

Table 7. Cost Assumptions for Hydrogen Production from Methane via CHHP .............................. 20

\section{List of Figures}

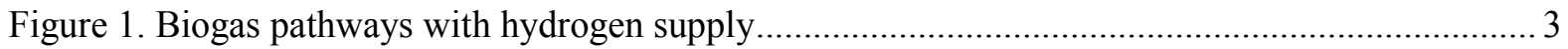

Figure 2. Estimated hydrogen potential from biogas sources...................................................... 4

Figure 3. Hydrogen potential from biogas sources and hydrogen fueling stations in California ........... 7

Figure 4. Potential methane production from biogas at landfills and WWTPs .................................. 9

Figure 5. Methane production cost from biogas at landfills and WWTPs ...................................... 11

Figure 6. Supply curve for potential methane production from biogas at landfills, WWTPs, and

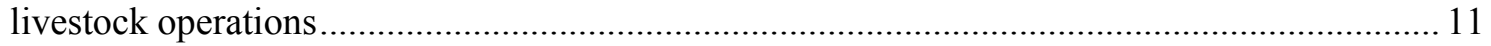

Figure 7. Potential hydrogen production via SMR from biogas at landfills and WWTPs .................. 13

Figure 8. Estimated cost of hydrogen produced via SMR from biogas at landfills............................. 14

Figure 9. Estimated cost of hydrogen produced via SMR from biogas at WWTPs ............................ 14

Figure 10. Supply curve for potential hydrogen production via SMR from biogas at landfills, WWTPs, and livestock operations

Figure 11. Cost of transporting hydrogen produced via SMR from landfills and WWTPs to the nearest

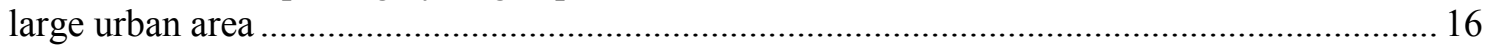

Figure 12. Supply curve for potential hydrogen production via SMR, delivered to the nearest large urban area, from biogas at landfills and WWTPs, using the lowest-cost delivery mode ............ 17

Figure 13. Supply curves for potential hydrogen production via SMR, delivered to the nearest large

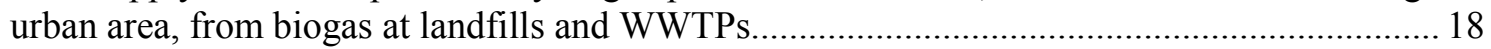

Figure 14. Potential hydrogen production via CHHP from biogas at landfills and WWTPs.............. 19

Figure 15. Estimated cost of hydrogen produced via CHHP from biogas at landfills ........................ 20

Figure 16. Estimated cost of hydrogen produced via CHHP from biogas at WWTPs....................... 21 
Figure 17. Supply curve for potential hydrogen production via CHHP from biogas at landfills,

WWTPs, and livestock operations ............................................................................. 21

Figure 18. Supply curve for potential hydrogen production via CHHP, delivered to the nearest large urban area, from biogas at landfills and WWTPs...

Figure 19. Supply curves for potential hydrogen production via CHHP, delivered to the nearest large urban area, from biogas at landfills and WWTPs.

Figure 20. Supply curves for potential hydrogen from processing biogas at landfills, WWTPs, and livestock operations as produced, or from landfills and WWTPs delivered to the nearest large urban area

Figure 21. Hydrogen production levelized costs for 10 pathways (excluding biogas). 


\section{Introduction}

Biogas is the gaseous product of anaerobic digestion (AD), a biological process in which microorganisms break down biodegradable material in the absence of oxygen. Biogas is comprised primarily of methane $\left(\mathrm{CH}_{4}\right)$ and carbon dioxide $\left(\mathrm{CO}_{2}\right)$ with trace amounts of other compounds. It can be produced from many sources including landfills, animal manure, wastewater treatment plants (WWTPs), and waste from the food-processing industry. It can also be produced from lignocellulosic material (e.g., crop residues and dedicated energy crops) through "dry" fermentation, co-digestion with other liquid waste material, or thermochemical means (e.g. gasification). Biogas can be used to generate electricity, and when upgraded, it can substitute for fossil natural gas and be used as a transportation fuel in the form of compressed or liquefied renewable natural gas. Additionally, biogas can be used to make plastics precursors.

Another area of interest is using biogas as a source for renewable hydrogen, which can power fuel cell electric vehicles (FCEVs). Hydrogen-powered FCEVs emit no tailpipe emissions other than water and are a clean transportation alternative to gasoline vehicles (Saur and Milbrandt 2014). In the United States, most hydrogen is currently produced by steam methane reforming (SMR) of natural gas. This SMR technology can also use purified biogas, or biomethane, as a natural gas substitute to provide a renewable source of hydrogen. Producing hydrogen from biomethane can contribute to energy security through the use of domestic sources, reduce demand for fossil fuels, and support state and local clean energy initiatives.

This analysis provides an overview of the market for biogas-derived hydrogen and its use in transportation applications. It examines the current hydrogen production technologies from biogas, capacity and production, infrastructure, and potential and demand, as well as key market areas. It also estimates the production cost of hydrogen from biogas and provides supply curves at national and point source levels. 


\section{Overview of Hydrogen Supply via Biogas Pathways}

Biogas is produced from a broad range of organic sources, typically via AD, but also through thermal processes such as gasification. Figure 1 indicates hydrogen supply options within the context of other biogas pathways, with biomass energy resources on the left following two general pathways: 1) conversion to biomethane for onsite utilization in compressed natural gas $(\mathrm{CNG})$ vehicles, pipeline injection, hydrogen production via SMR, and use in tri-generation fuel cells ${ }^{1}$, or 2) conversion to processed solids for use in gasification or electricity production systems. Solids such as agricultural residues and some municipal solid waste (MSW) streams (e.g., yard trimmings) can also be inputs for co-digestion systems, and can improve the overall environmental performance of the resulting biogas system on a life cycle basis (Poeschl et al. 2012). Purification of the biogas produced from AD involves removal of water, hydrogen sulfide $\left(\mathrm{H}_{2} \mathrm{~S}\right)$, hydrocarbons, and other impurities, while upgrading to biomethane involves removing $\mathrm{CO}_{2}$ to increase calorific content. Examples of particular constituents of concern for purification are reviewed in the biomethane standards for pipeline injection from the California Public Utilities Commission (CPUC 2014). Depending upon the source, biogas may contain 15-60\% $\mathrm{CO}_{2}$ while typical natural gas pipeline applications require less than $3 \% \mathrm{CO}_{2}$ content (Ryckesbosch et al. 2011). Once injected into natural gas pipelines, biomethane can be compressed and dispensed to CNG vehicles, liquefied for use in liquid natural gas (LNG) vehicles, distributed to conventional natural gas demands, or converted to hydrogen for FCEVs. More complete discussions of biogas systems and pathway components can be found in Poeschl et al. (2010) and Deublein and Steinhauser (2011).

Biomethane can also be used directly in SMR units for hydrogen production, with hydrogen delivery and dispensing infrastructure requirements dependent upon the logistics of biomethane production and hydrogen demand. This pathway is a primary focus of the present study. Biomethane can also be used for (onsite) electricity production in conventional generators or stationary fuel cells, with heat recovery improving the energy balance of biogas production (Poeschl et al. 2012). Use in molten carbonate tri-generation fuel cells results in hydrogen, electricity, and heat, which is the second key hydrogen pathway addressed in the present study.

Processed biomass solids can also be converted to electricity directly in conventional combustion devices, or to hydrogen directly by way of gasification. Gasification systems generate a syngas product (primarily hydrogen and carbon monoxide) that can be converted to hydrogen or to biomethane by way of methanation, and can also generate electricity as a byproduct (Saxena et al. 2008). The resulting hydrogen can be used in fuel cell vehicles, or the resulting biomethane can be injected into natural gas pipeline systems, though mixing of hydrogen into natural gas pipelines (not shown in Figure 1) is also an option (Melaina et al. 2013). Direct gasification of biomass-to-hydrogen is interesting from a technical and market potential perspective, but this pathway is not within the scope of the present study.

\footnotetext{
${ }^{1}$ Tri-generation fuel cells produce electricity, heat, and hydrogen.
} 


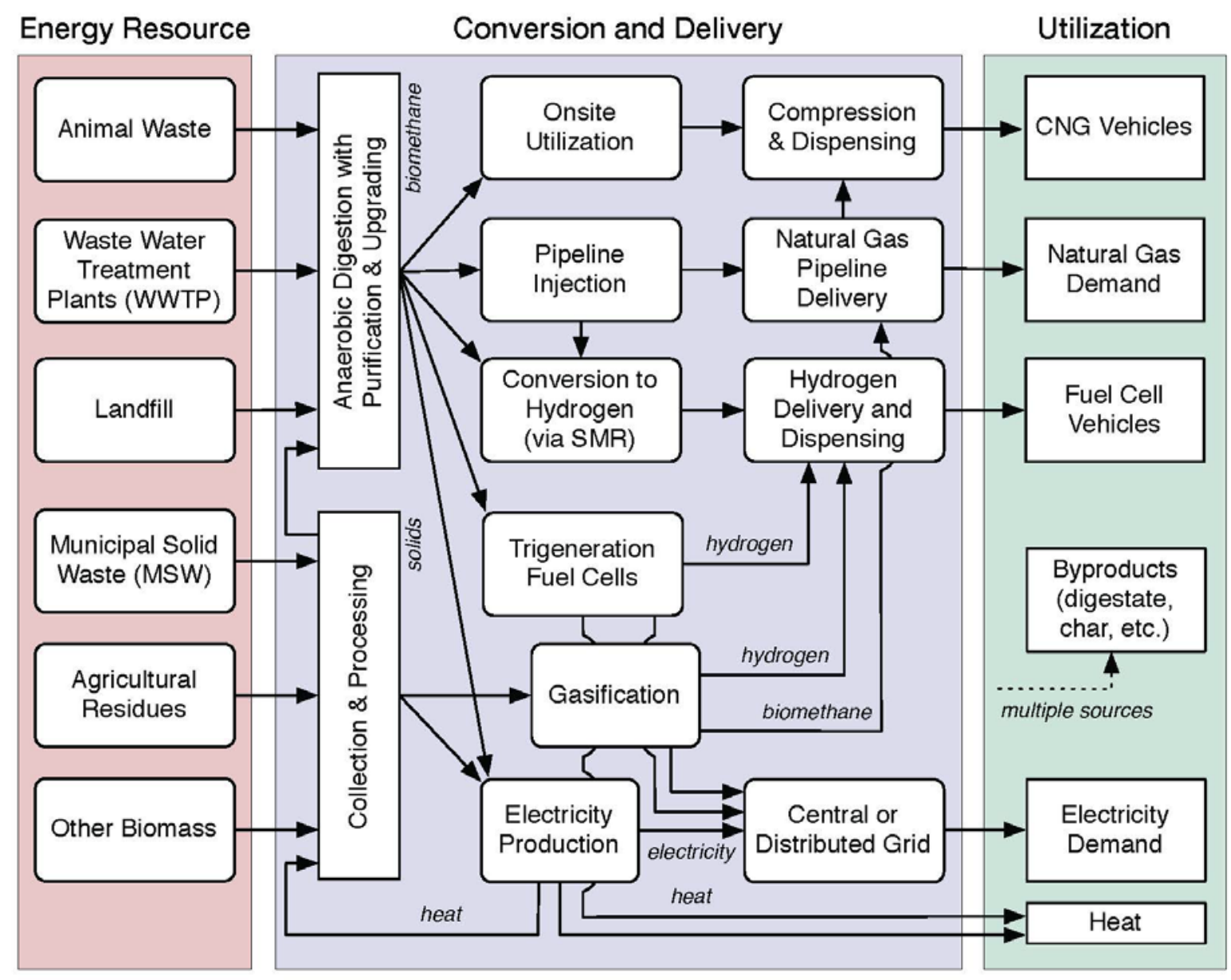

Figure 1. Biogas pathways with hydrogen supply 


\section{Market Status}

\subsection{Resource Potential}

The hydrogen potential from biogas is estimated at about 4.2 million tonnes per year, but only half of that is considered to be available given other uses of biogas, namely as a source of electricity (Saur and Milbrandt 2014). Landfills provide the largest source of biogas for hydrogen (from both a total perspective as well as the current net availability), followed by WWTPs, animal manure, and wastes from the food-processing industry. To put this potential in perspective, the United States produces over 9 million tonnes of hydrogen per year (NAS 2013) and projected hydrogen demand for FCEVs in 2030 is about 15 million tonnes, sufficient to fuel 60 million vehicles or $20 \%$ of the US light duty vehicles fleet (ANL 2005). Figure 2 illustrates the estimated hydrogen potential from biogas sources by state. California has the highest potential given the state's many WWTPs, dairy operations, and food-processing facilities.

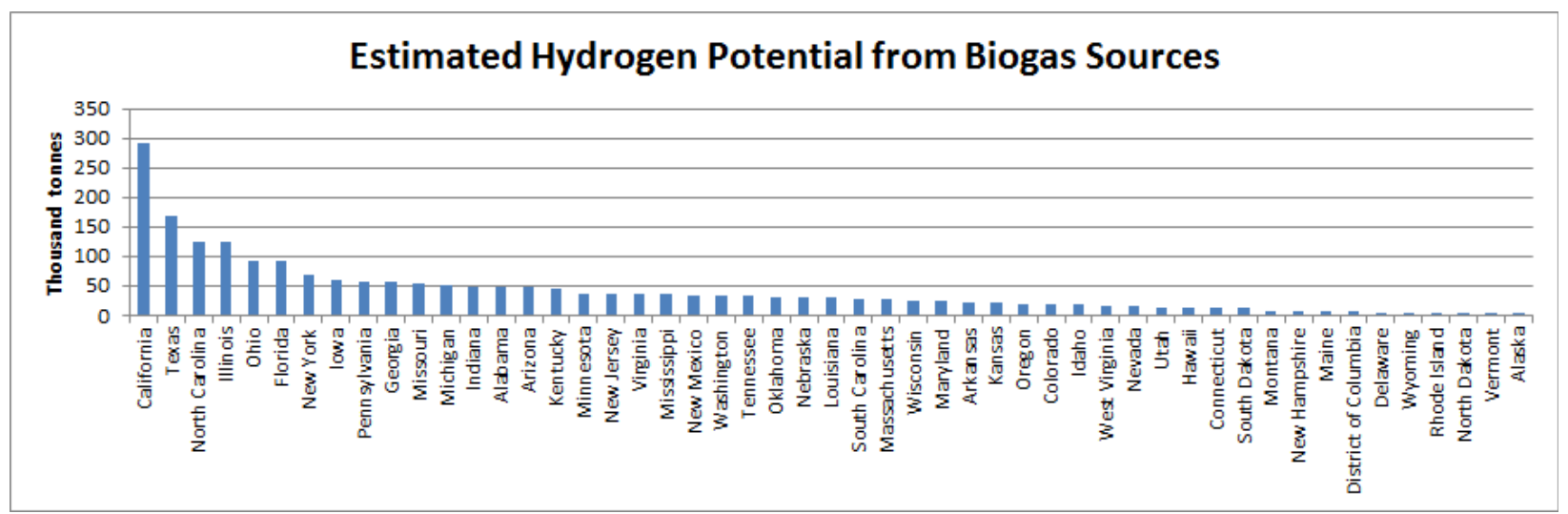

Figure 2. Estimated hydrogen potential from biogas sources

Source: Saur and Milbrandt 2014

\subsection{Current Capacity and Production}

Most WWTPs already have anaerobic digesters onsite, and thus they are often considered the "low-hanging fruit" in biogas utilization. There are several WWTPs using biogas-powered fuel cells to produce electricity and offset grid purchases (Table 1). However, as of summer 2014, only one demo plant was producing hydrogen to power fuel cell vehicles, located at the Orange County Sanitation District's WWTP in Fountain Valley, California. The system produces approximately $100 \mathrm{~kg}$ of hydrogen per day and refuels between 25 and 50 FCEVs per day (U.S. DOE 2011). In addition to hydrogen, the fuel cell produces electricity and heat, making it a trigeneration system. It is expected that as more fuel cells come online, growing demand for sustainable fuel will stimulate growth in capacity of biogas-derived hydrogen to power FCEVs. 
Table 1. Examples of Biogas-powered Fuel Cell Projects

\begin{tabular}{|c|c|c|c|}
\hline \multicolumn{3}{|c|}{ Wastewater / Organic Conversion } & \multirow{2}{*}{$\begin{array}{l}\text { Capacity } \\
\text { in } \mathbf{k g} / \mathrm{hr}\end{array}$} \\
\hline Source & Project & Location & \\
\hline Anaer. Dig. Gas & El Estero Fuel Cell Project - Hydrogen Fueling Station & Santa Barbara, CA & 42.52 \\
\hline Anaer. Dig. Gas & Los Angeles County Palmdale & Palmdale, CA & 21.26 \\
\hline Anaer. Dig. Gas & King's County Waste-Water Treatment Plant & King County, WA & 85.03 \\
\hline Anaer. Dig. Gas & Sierra Nevada Brewery & Chico, CA & 85.03 \\
\hline Anaer. Dig. Gas & Wastewater Treatment Facility & Tulare, $\mathrm{CA}$ & 63.78 \\
\hline Anaer. Dig. Gas & City of Rialto's wastewater treatment facility & Rialto, CA & 76.53 \\
\hline Anaer. Dig. Gas & Turlock Irrigation District & Turlock, CA & 102.04 \\
\hline Anaer. Dig. Gas & Eastern Municipal Water District (EMWD) & Moreno Valley, CA & 63.78 \\
\hline Anaer. Dig. Gas & Dublin San Ramon & San Ramon, CA & 51.02 \\
\hline Anaer. Dig. Gas & Gills Onion Plant & Gills Onion, CA & 51.02 \\
\hline Anaer. Dig. Gas & Riverside Treatment Plant & Riverside, CA & 85.03 \\
\hline \multirow[t]{2}{*}{ Bioreactor } & Welch's Grape Juice Factory & North East & N/A \\
\hline & & Sum & 727.04 \\
\hline
\end{tabular}

Source: NHA 2010

\subsection{Infrastructure}

At present, the hydrogen fuel station network and FCEVs fleet are in an early demonstration phase. As of July 2014, there were about 12 operational publicly accessible hydrogen fueling stations (AFDC 2014). One is located in Connecticut, another one in South Carolina, and the rest are in California. There are about 40 operational private hydrogen stations owned by auto manufacturers and federal, state, or local governments (AFDC 2014). While these private stations are fairly equally distributed across the country, a few clusters exist in California, New York and Michigan. About 48 hydrogen stations are in the planning phase and almost all are in California.

Since 2009, several vehicle manufacturers have made prototypes and demonstration light-duty hydrogen vehicles. Test vehicles are also available in limited numbers to select organizations with access to hydrogen fueling stations (AFDC 2014). In early 2014, Hyundai began leasing its Tucson FCEV in southern California making use of the clusters of hydrogen fueling stations. Toyota is introducing their first mass-market fuel cell vehicle, the Mirai, in fall 2015.

\subsection{Key Markets}

California is emerging as a key area in the biogas-to-hydrogen market. Not only does the state have the highest hydrogen potential from biogas - it also has existing infrastructure and favorable policies to support further development of this industry. California has been a U.S. leader in developing hydrogen infrastructure in preparation for the 2015-2017 commercial launch of FCEVs. As mentioned earlier, the state has the world's first tri-generation fuel cell and hydrogen energy station that uses biogas. Most of the currently operating and planned hydrogen fueling stations are in California. A total of 51 stations are expected to be operational statewide by the end of 2015, up from the 21 public and private stations currently operating (ARB 2014). These stations are expected to have a total capacity of 9,400 $\mathrm{kg}$ of hydrogen per day (about 3,431 tonnes/year), a supply that could be provided in whole (and much more) by biogas-derived hydrogen (as seen in Figure 2). California has recently been the focus for introduction of the first mass-market FCEV, the Hyundai Tucson, and rollout announcements 
from Toyota and Honda. About 125 FCEVs are currently registered with the California DMV; projections are that the fleet will grow to 6,650 by the end of 2017 (ARB 2014).

Figure 3 illustrates the hydrogen potential from biogas by county in California (based on Saur and Milbrandt [2014]) and its relation to existing and planned hydrogen fueling stations. As can be seen, the counties with highest hydrogen potential from biogas either overlap or are in close proximity to the two existing hydrogen station clusters in the state: South San Francisco/Berkeley and greater Los Angeles area (Santa Monica/West Los Angeles, Torrance, and Irvine/Southern Orange County). This proximity could ensure domestic supply of renewable hydrogen fuel, aid compliance with the state's clean energy policies, and further the development of hydrogen industry in the area. California is already the nation's front runner in biogas utilization projects (primarily onsite power generation); thus, there is potential for synergies with hydrogen production. However, despite the numerous projects, biogas remains underutilized, which provides an opportunity for expansion of biogas utilization through hydrogen fuel production. For example, there are over 1,700 dairy farms in California, of which about half are considered good candidates for biogas projects, but only 11 currently capture biogas (Amon et al. 2011; EPA 2011; ARB 2013). 


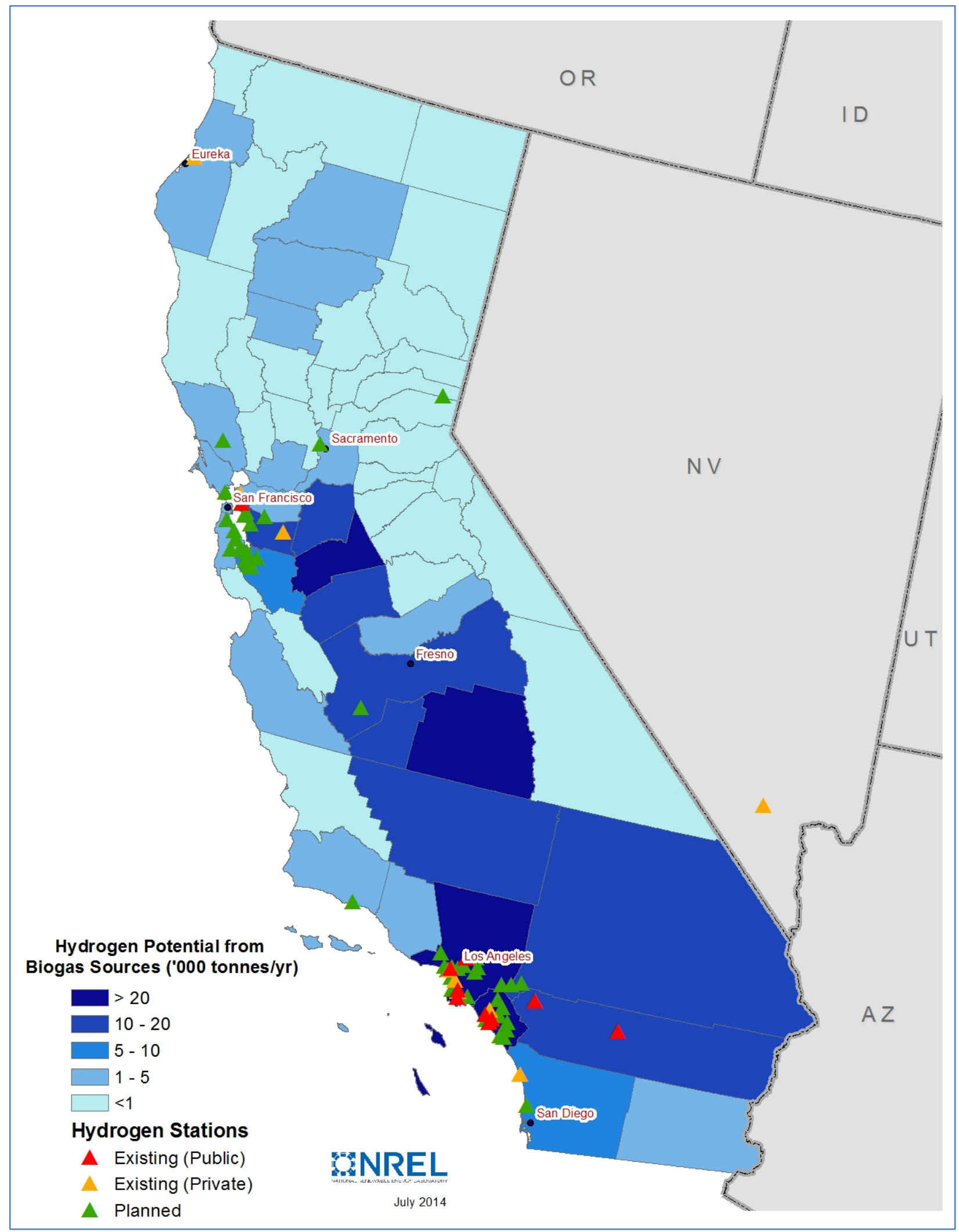

Figure 3. Hydrogen potential from biogas sources and hydrogen fueling stations in California 


\section{Supply Curves and Production Cost}

This analysis uses the Scenario Evaluation, Regionalization \& Analysis (SERA) model. SERA is a geospatially and temporally oriented infrastructure analysis model that uses resource availability and technology cost to determine optimal hydrogen production and delivery scenarios (OpenEI 2014). It supports the study of hydrogen infrastructure build-out and endgame scenarios and can be used to develop regional supply curves based on optimization results.

Production costs and supply curves are provided for biomethane and two hydrogen scenarios: (i) hydrogen produced from biomethane using SMR technology and (ii) hydrogen produced from biomethane via fuel cells. These estimates include methane supply from landfills, WWTPs, and livestock operations. Production costs and supply curves for biomethane and biomethane-derived hydrogen from landfills and WWTPs are provided at point locations and at a national level, while those related to biomethane and biomethane-derived hydrogen from animal manure are estimated at national level due to lack of detailed information about individual livestock operations (e.g., size, number of animals, and digester type) below that level.

\subsection{Biomethane}

The quantity of methane potentially available from landfills and WWTPs for hydrogen production is derived from Saur and Milbrandt (2014) and illustrated in Figure 4. Note that this estimate assumes that anaerobic digesters are present or would be present at WWTPs (since data sources are insufficiently detailed to distinguish sites where anaerobic digesters are or could be implemented). The landfills tend to be a much larger potential source of methane, but there are fewer landfills than there are WWTPs. Quantities of methane potentially available at livestock operations are taken from Murray et al. (2014), but are not shown on the map below due to lack of site-specific information. 


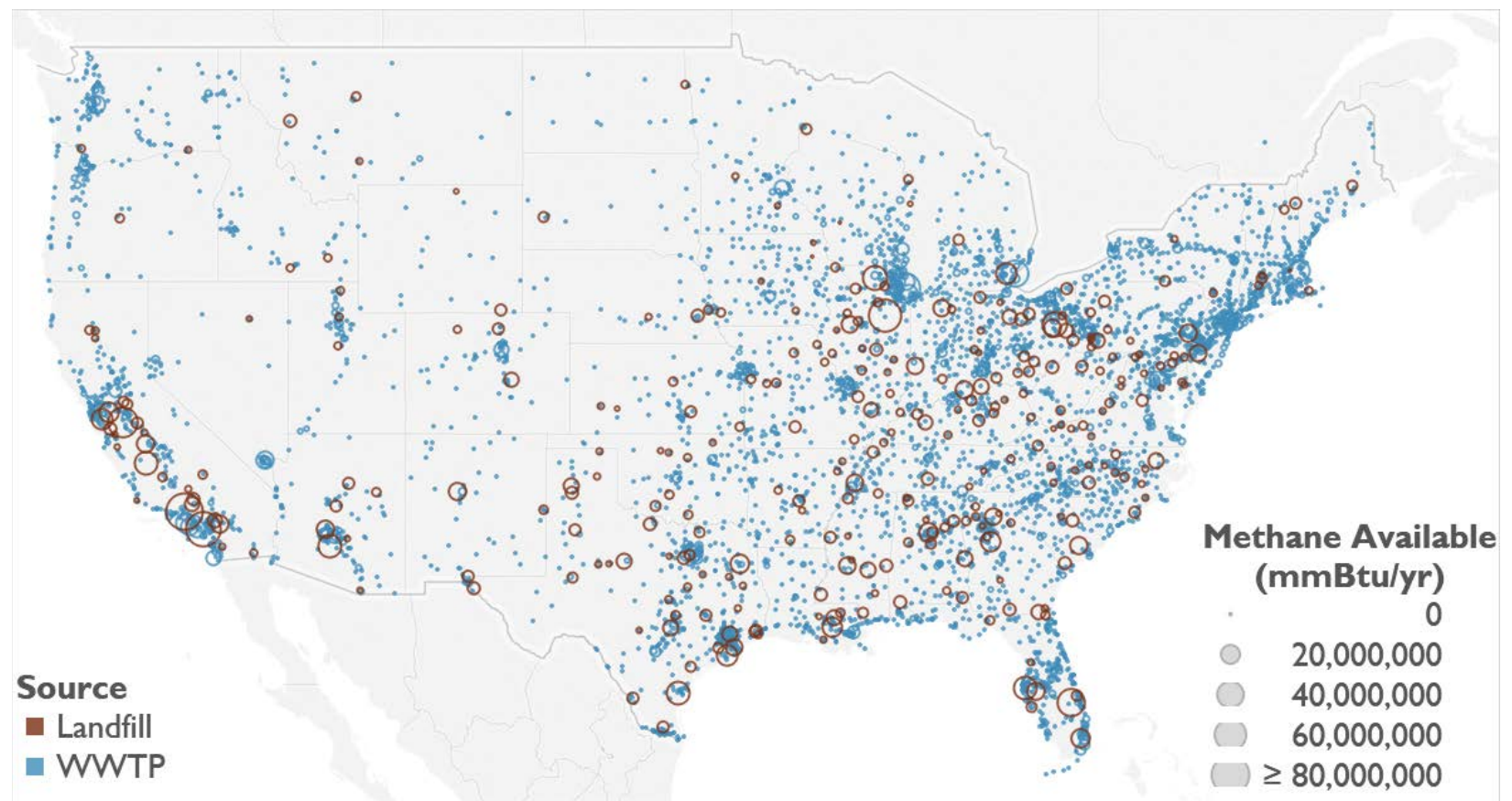

Figure 4. Potential methane production from biogas at landfills and WWTPs

The production costs of methane from landfills, WWTPs, and livestock operations are estimated using the methodology outlined in Murray et al. (2014) and Vegh (2014), which includes recovery, upgrading, and purification, and they are shown in Table 2 through Table 4 . In general, because of the wide variety in resource quality and accessibility, there is considerable uncertainty and subjectivity involved in estimating methane extraction costs from biogas sources; this report relies on costs derived from Murray et al. (2014) and Vegh (2014) and does not undertake a comprehensive first principles analysis of costs or a synthesis of all available literature on the subject. The methane production costs are shown for various landfill and WWTP sizes, as well as livestock operation sizes and digester type. The costs in Table 2 through Table 4 vary with facility size due to economies of scale, the granularity of unit operations, and diminishing returns. Figure 5 illustrates the result of applying these costs to the resource locations and sizes. It highlights that the lowest-cost methane is available at large landfills. When the methane cost and quantity data are summarized at the national scale, we arrive at the supply curves show in Figure 6 . These cost curves are derived by applying costs in Table 2 through Table 4 to the inventory of landfills, wastewater treatment plants, and liverstock operations. The costs include a $\$ 1.20 / \mathrm{mmBtu}$ tariff for distribution of the methane via existing natural gas pipeline infrastructure, which roughly accounts for the integration of the biomethane within the natural gas pipeline system Murray et al. (2014), and assume that anaerobic digesters are already present at WWTPs (Murray et al. 2014). The overall results show that landfills and WWTPs dominate the low-cost supply of methane, but that there is an appreciable amount of moderate-cost methane from livestock operations. 
Table 2. Methane Cost Assumptions for Landfills

\begin{tabular}{|c|c|}
\hline Landfill Output (scf/hr) & Methane (\$/mmBtu) \\
\hline$<6,000$ & 10.334 \\
\hline $6,000-21,000$ & 5.426 \\
\hline $21,000-42,000$ & 2.851 \\
\hline $42,000-72,000$ & 2.933 \\
\hline $72,000-120,000$ & 2.740 \\
\hline $120,000-300,000$ & 3.110 \\
\hline$>300,000$ & 2.014 \\
\hline
\end{tabular}

Source: Derived from Vegh $2014^{2}$

Table 3. Methane Cost Assumptions for WWTPs

\begin{tabular}{|c|c|}
\hline Wastewater Flow (MGD) & Methane (\$/mmBtu) \\
\hline$>200$ & 1.693 \\
\hline $100-200$ & 1.410 \\
\hline $75-100$ & 1.532 \\
\hline $50-75$ & 2.088 \\
\hline $20-50$ & 3.235 \\
\hline $10-20$ & 2.906 \\
\hline $5-10$ & 5.737 \\
\hline $1-5$ & 16.503 \\
\hline
\end{tabular}

Source: Derived from Murray et al. 2014 and Vegh 2014

Table 4. Methane Cost Assumptions for Livestock Operations

\begin{tabular}{|c|c|c|c|}
\hline Farm Type & Digester & Biogas (scf/hr) & Methane (\$/mmBtu) \\
\hline Dairy & Complete mix & 1,636 & 12.4 \\
\hline Dairy & Complete mix & 3,182 & 9.6 \\
\hline Dairy & Complete mix & 9,024 & 7.7 \\
\hline Swine & Covered lagoon & 634 & 23.7 \\
\hline Swine & Covered lagoon & 1,226 & 13.7 \\
\hline Swine & Covered lagoon & 6,436 & 5.2 \\
\hline Beef & Plug flow & 288 & 69.4 \\
\hline Beef & Plug flow & 568 & 41 \\
\hline Beef & Plug flow & 2,153 & 19.4 \\
\hline
\end{tabular}

Source: Derived from Murray et al. 2014 and Vegh 2014

${ }^{2}$ The cost data in Table 2 and 3 show some minor non-monotonicity due to the assumptions that Murray et al. (2014) and Vegh (2014) make regarding the system designs, discounting of cash flows, and the categorization of system sizes. 


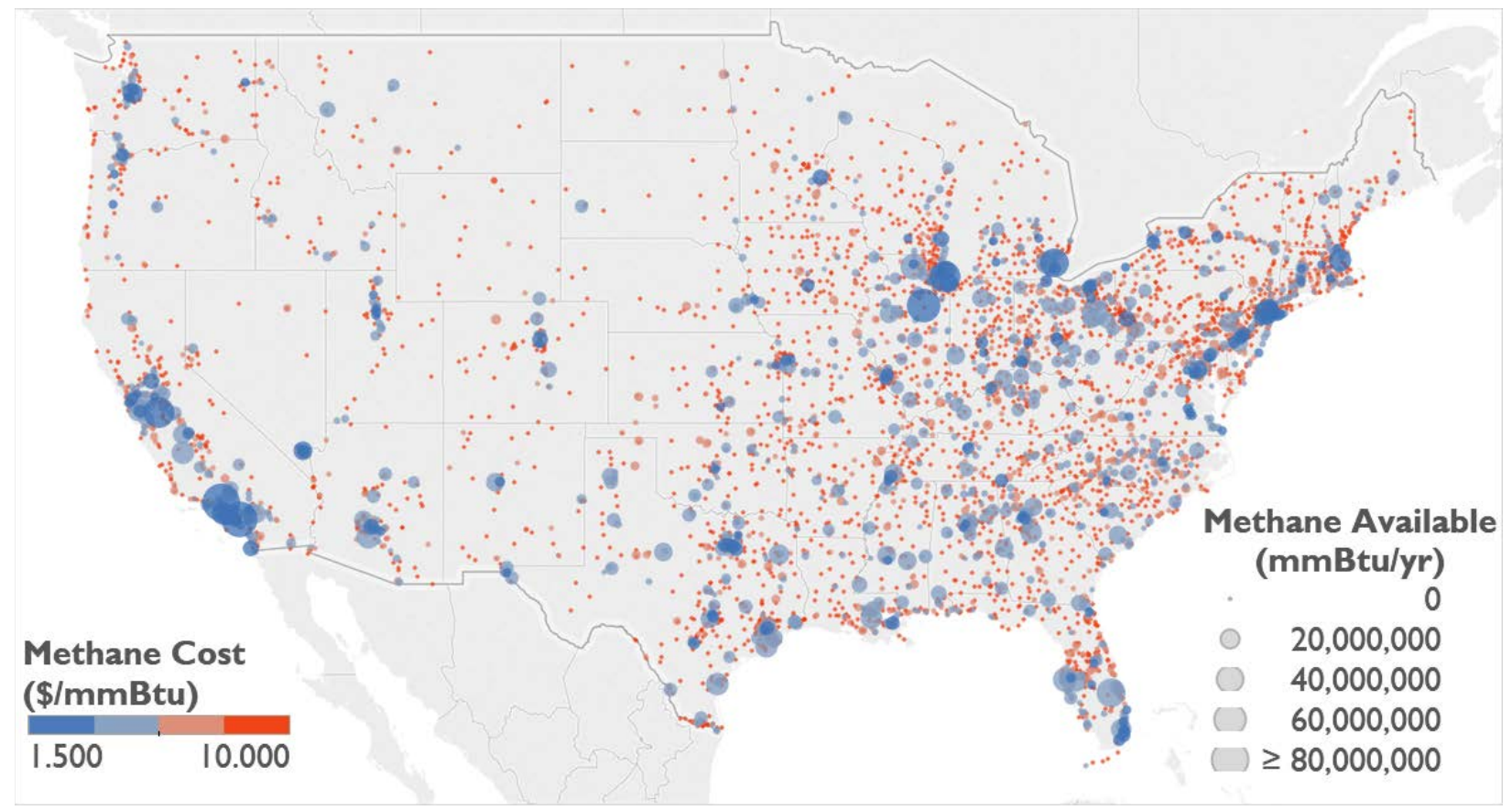

Figure 5. Methane production cost from biogas at landfills and WWTPs

Note: The methane production cost includes a $\$ 1.20 / \mathrm{mmBtu}$ tariff for distribution of the methane via existing natural gas pipelines and assumes that anaerobic digesters are already present at WWTPs.

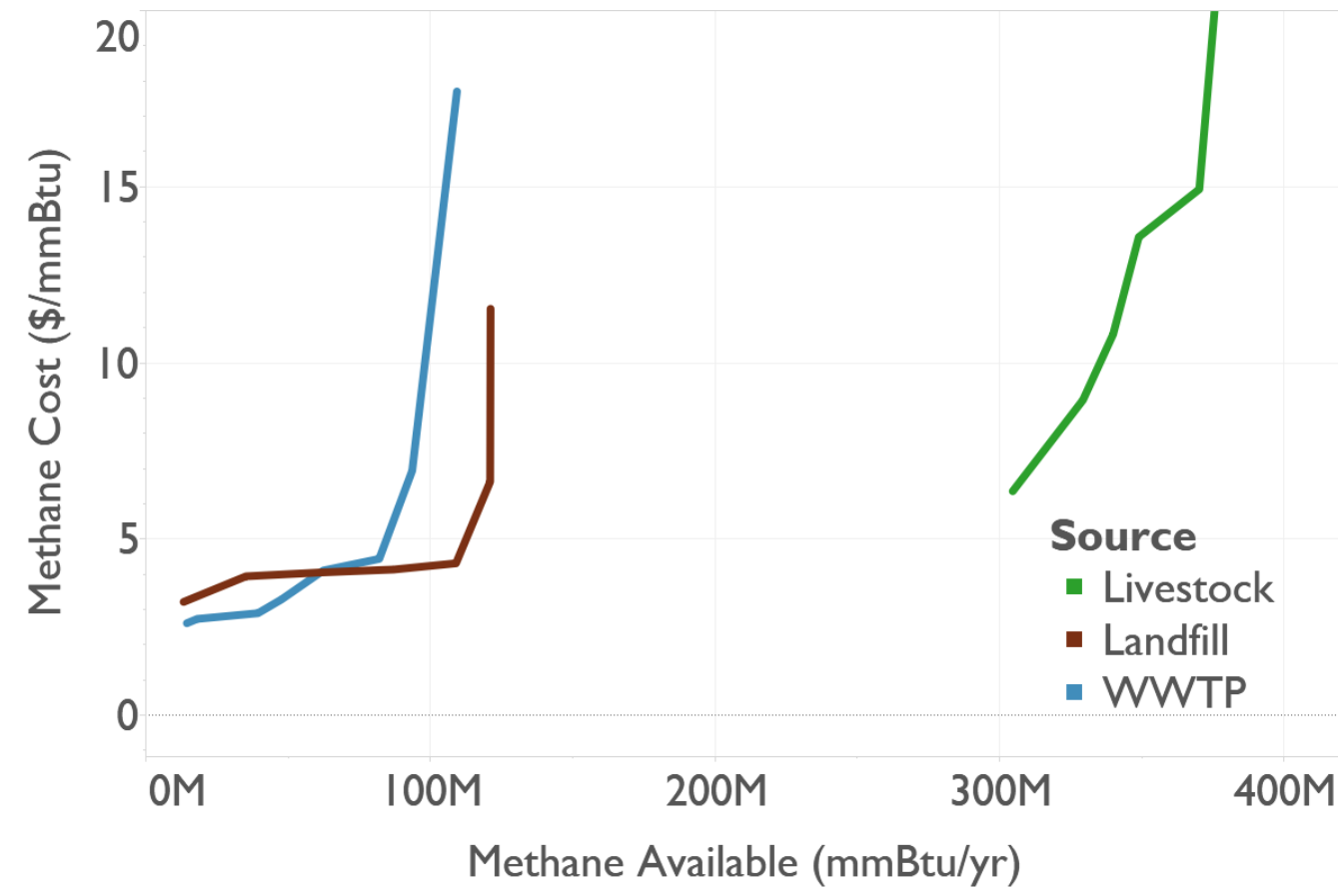

Figure 6. Supply curve for potential methane production from biogas at landfills, WWTPs, and livestock operations

Note: The methane production cost includes a $\$ 1.20 / \mathrm{mmBtu}$ tariff for distribution of the methane via existing natural gas pipelines and assumes that anaerobic digesters are already present at WWTPs. 


\subsection{Hydrogen from Biomethane Using SMR Technology}

The quantity of hydrogen that could be produced from landfill- and WWTP-derived biomethane is taken from Saur and Milbrandt (2014) and displayed in Figure 7 (as noted earlier in this report, point-specific data on livestock operations is not available thus we are unable to estimate biogas potential at a finer geographic scale.) Similar to the biomethane distribution (Figure 4), landfills are a much larger potential source of hydrogen, but there are fewer landfills than there are WWTPs. Hydrogen production costs from biomethane using SMR are estimated using inputs from the Department of Energy's H2A Production Models for current-year central and forecourt SMR with plant-size scaling (U.S. DOE 2014), with the addition of the methane production costs in Tables 2 through 4, but without the $\$ 1.20 / \mathrm{mmBtu}$ tarrif mentioned in the previous section, since the biogas is not delivered into the natural gas pipeline system. These assumptions are illustrated in Table 5: the production costs (not the dispensing costs) from both the centralized and forecourt H2A production models were used, within their scaling range, and beyond that scaling range, multiple units production were used, and the choice of central vs. forecourt production was made on the basis of lowest cost at a particular facility size. The wide range of costs at point of production is shown in Figure 8 and Figure 9. The cost of hydrogen produced via SMR from biogas at landfills is low at most locations. This is primarily due to economies of scale available at landfills with a large biogas resource. The cost of hydrogen produced via SMR from biogas at large WWTPs is also low, but varies substantially among smaller facilities due to the minimal resource available at those smaller facilities, and the greater cost of processing at smaller facilities. The integration of the production costs and quantity data for hydrogen from biomethane using SMR, and summarizing them at a national level, results in the supply curve depicted in Figure 10. The overall results are similar to those for biomethane: landfills and WWTPs dominate the low-cost supply of hydrogen, but there is an appreciable amount of moderate-cost hydrogen from livestock operations (because the livestock-derived biogas resource data does not represent individual facilities, the livestock cost curve in Figure 10 only has a few points and starts at a higher initial quantity than the other cost curves). 


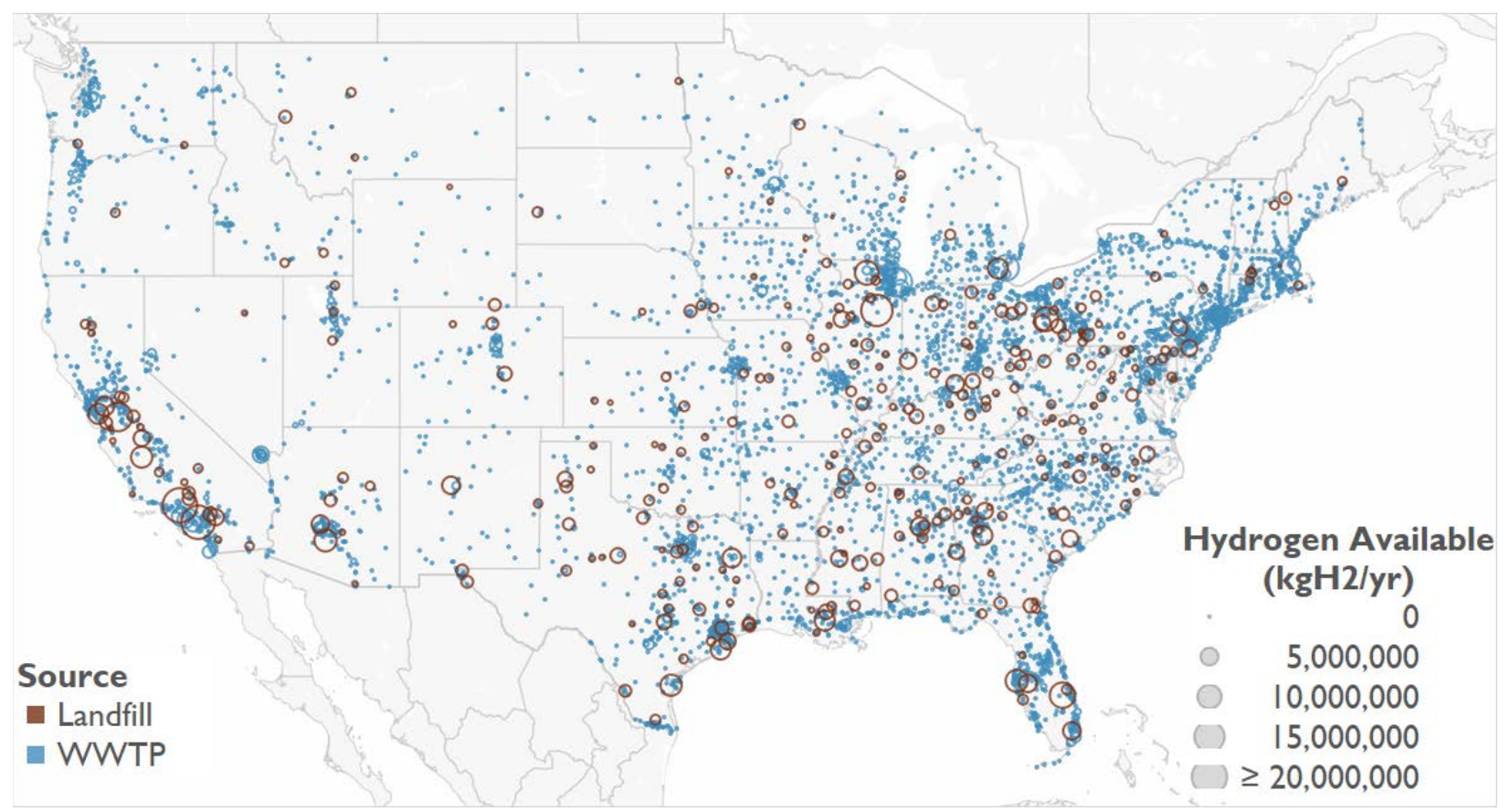

Figure 7. Potential hydrogen production via SMR from biogas at landfills and WWTPs

Table 5. Cost Assumptions for Hydrogen Production from Methane via SMR

\begin{tabular}{|c|c|}
\hline Plant Capacity (kgH2/day) & Hydrogen Cost (\$/kgH2) \\
\hline 50,000 & 0.89 \\
\hline 30,000 & 1.09 \\
\hline 20,000 & 1.29 \\
\hline 15,000 & 1.46 \\
\hline 10,000 & 1.74 \\
\hline 5,000 & 2.38 \\
\hline 3,000 & 2.75 \\
\hline 2,000 & 2.73 \\
\hline 1,500 & 2.94 \\
\hline 1,000 & 3.14 \\
\hline 500 & 3.81 \\
\hline 300 & 4.39 \\
\hline 200 & 5.46 \\
\hline 150 & 6.48 \\
\hline 100 & 8.37 \\
\hline 50 & 13.78 \\
\hline 30 & 21.86 \\
\hline
\end{tabular}

Source: Derived from U.S. DOE 2014 (H2A Production Model) 


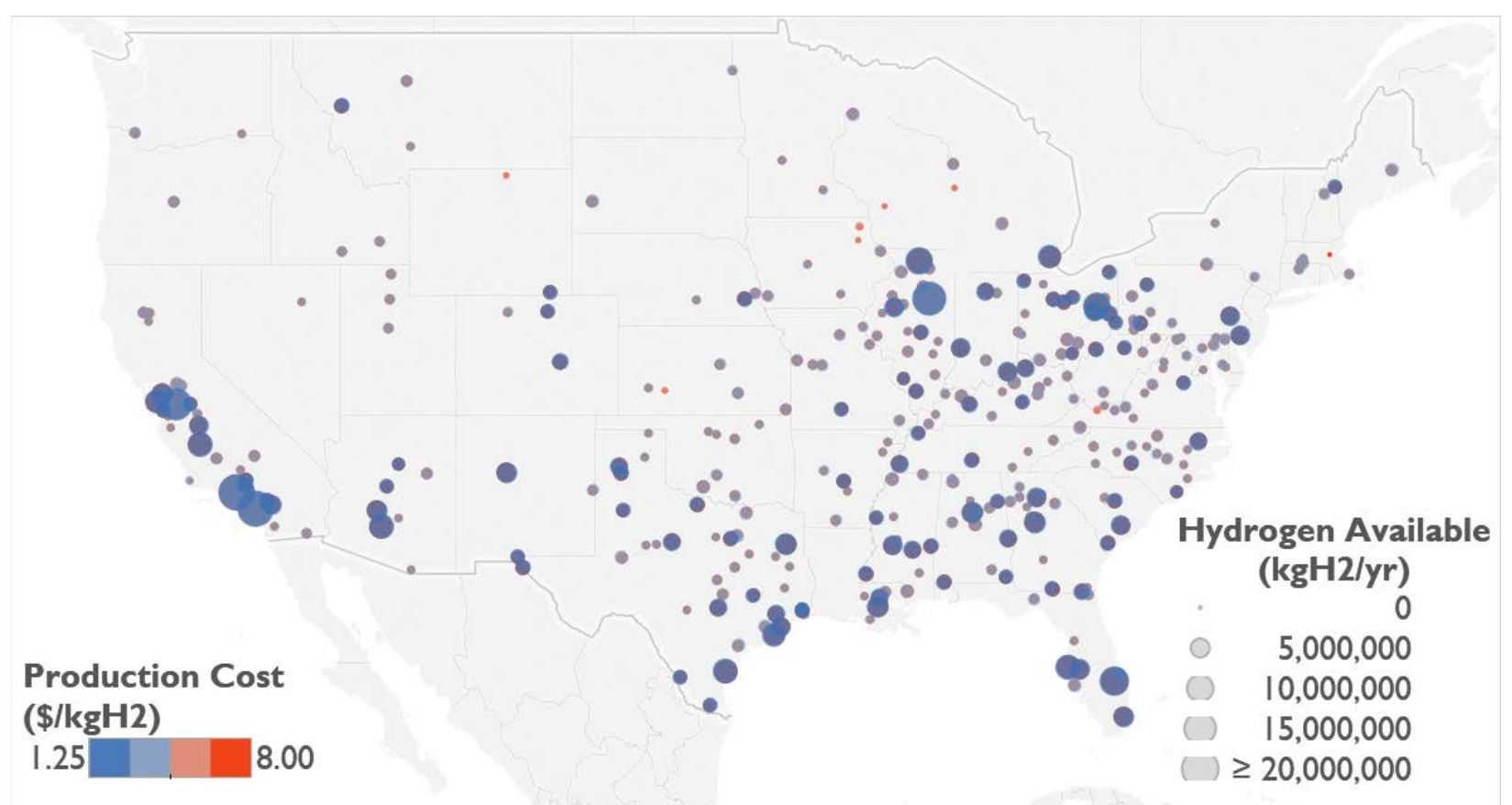

Figure 8. Estimated cost of hydrogen produced via SMR from biogas at landfills

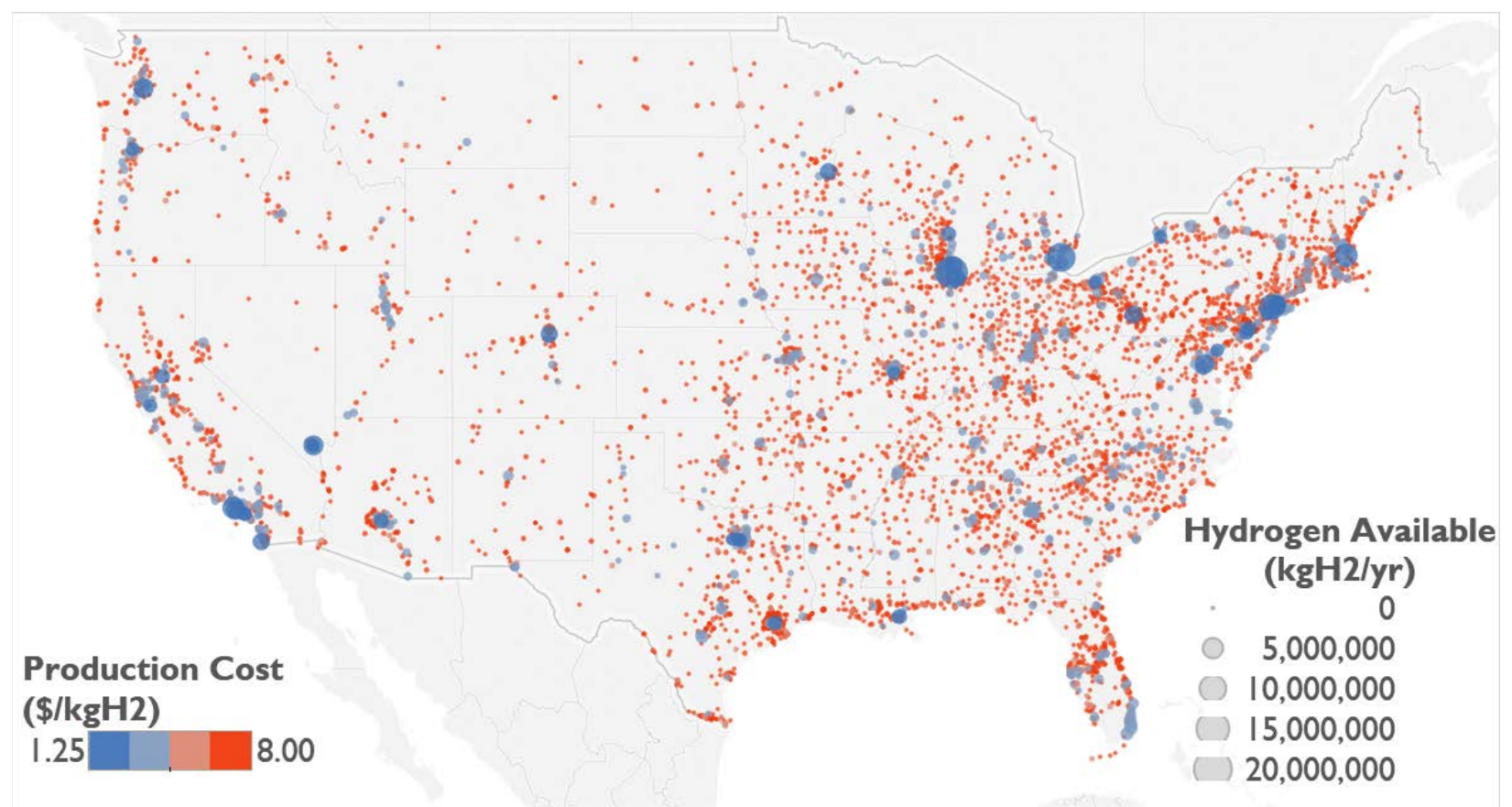

Figure 9. Estimated cost of hydrogen produced via SMR from biogas at WWTPS 


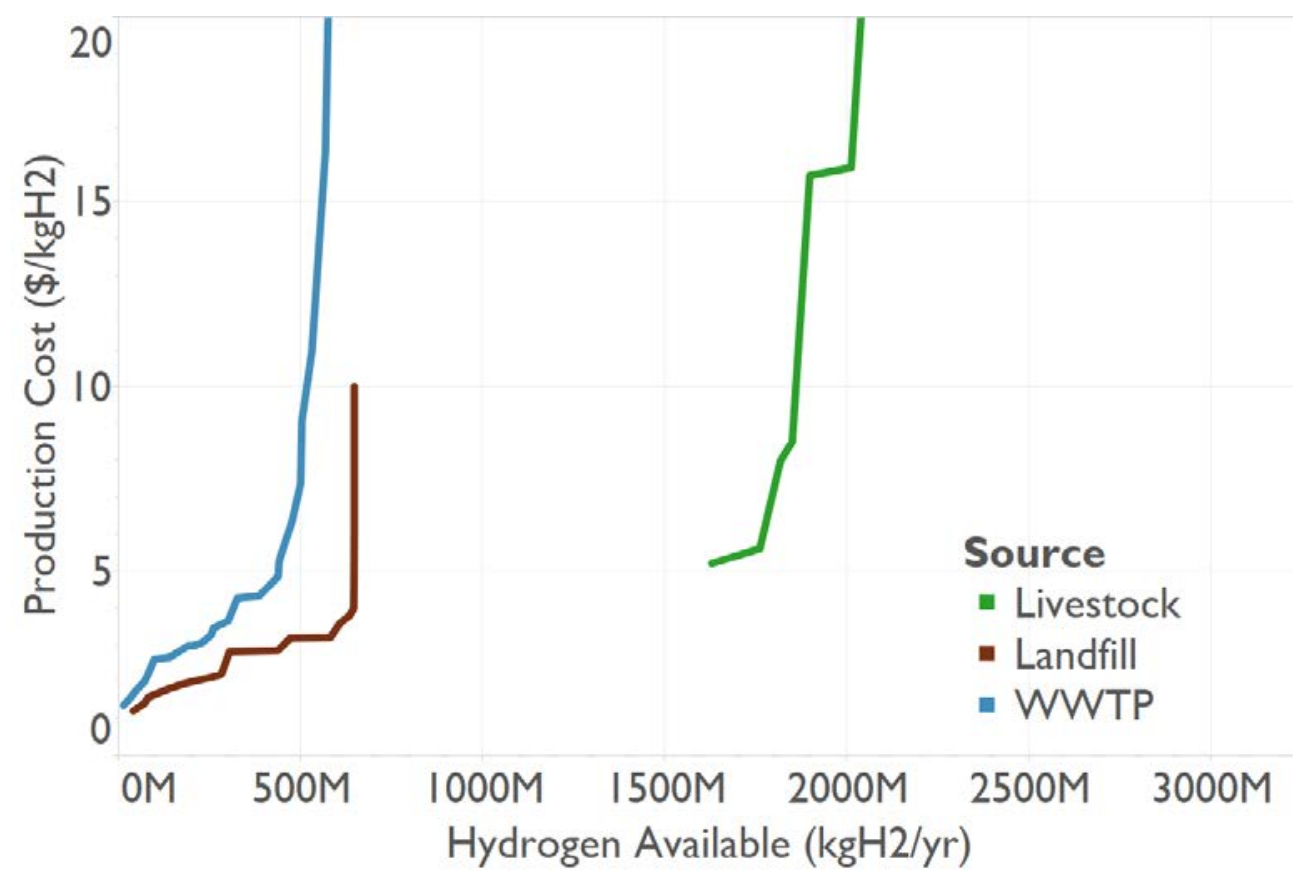

Figure 10. Supply curve for potential hydrogen production via SMR from biogas at landfills, WWTPs, and livestock operations

Because additional costs would be incurred in delivering the hydrogen to demand centers, we also estimate (using a linear interpolation of delivery costs in Table 6, which represent the lowest cost among gaseous truck, liquid truck, pipeline, or rail transport) a delivered cost of the hydrogen to the nearest of the 25 largest urban areas (Figure 11). The transportation distances are approximate and simply represent a straight-line connection rather than a network. The transportation costs include all of the $\mathrm{H} 2 \mathrm{~A}$ delivery component costs relevant to the delivery pathway. The results of this analysis illustrate that low delivery costs of hydrogen produced from biogas are possible in all urban areas. However, cities in the eastern states and along coastal areas have a larger access to nearby biogas sources, which is no surprise given that landfills and WWTPs are generally located near population centers, and that contributes to low delivery costs. On the other hand, the biogas sources in central states are more spread out and there are fewer urban areas, which increases hydrogen delivery costs. Given that livestock operations are primarily concentrated in the Midwest, it is expected that the urban areas in that region would have additional sources of biogas-derived hydrogen delivered at low costs; however, the livestock resource is not displayed on Figure 11 because the resource data we use does not have geographic specificity. 
Table 6. Cost Assumptions for Hydrogen Delivery

\begin{tabular}{|c|c|c|c|c|c|c|c|c|}
\hline \multicolumn{7}{|c|}{ Distance [km] } \\
\hline Capacity [kg/day] & $\mathbf{0}$ & $\mathbf{5 0}$ & $\mathbf{1 0 0}$ & $\mathbf{2 0 0}$ & $\mathbf{5 0 0}$ & $\mathbf{1 , 0 0 0}$ & $\mathbf{2 , 0 0 0}$ & $\mathbf{5 , 0 0 0}$ \\
\hline 1,000 & 5.26 & 5.70 & 5.70 & 6.56 & 8.07 & 10.67 & 16.38 & 33.83 \\
\hline 2,000 & 3.47 & 3.91 & 3.91 & 4.77 & 6.28 & 8.88 & 13.64 & 18.41 \\
\hline 5,000 & 2.85 & 3.29 & 3.29 & 4.15 & 5.66 & 6.31 & 7.14 & 9.44 \\
\hline 10,000 & 2.77 & 3.21 & 3.21 & 4.07 & 4.84 & 4.93 & 5.18 & 6.71 \\
\hline 20,000 & 2.57 & 3.01 & 3.01 & 3.83 & 4.09 & 4.39 & 4.61 & 6.00 \\
\hline 50,000 & 2.39 & 2.83 & 2.83 & 3.24 & 3.50 & 3.66 & 3.87 & 5.11 \\
\hline 100,000 & 2.27 & 2.71 & 2.71 & 2.90 & 3.16 & 3.32 & 3.51 & 4.70 \\
\hline 200,000 & 2.20 & 2.64 & 2.64 & 2.89 & 3.15 & 3.29 & 3.48 & 4.65 \\
\hline 500,000 & 2.13 & 2.56 & 2.56 & 2.69 & 2.95 & 3.10 & 3.28 & 4.43 \\
\hline $1,000,000$ & 2.11 & 2.55 & 2.55 & 2.69 & 2.94 & 3.10 & 3.29 & 4.46 \\
\hline $2,000,000$ & 2.10 & 5.08 & 5.08 & 2.67 & 2.88 & 6.18 & 3.28 & 4.45 \\
\hline $5,000,000$ & 2.09 & 2.52 & 2.52 & 2.65 & 2.88 & 6.14 & 3.26 & 4.43 \\
\hline
\end{tabular}

Source: Bush et al. 2011; Bush et al. 2013; OpenEl 2014 (SERA model)

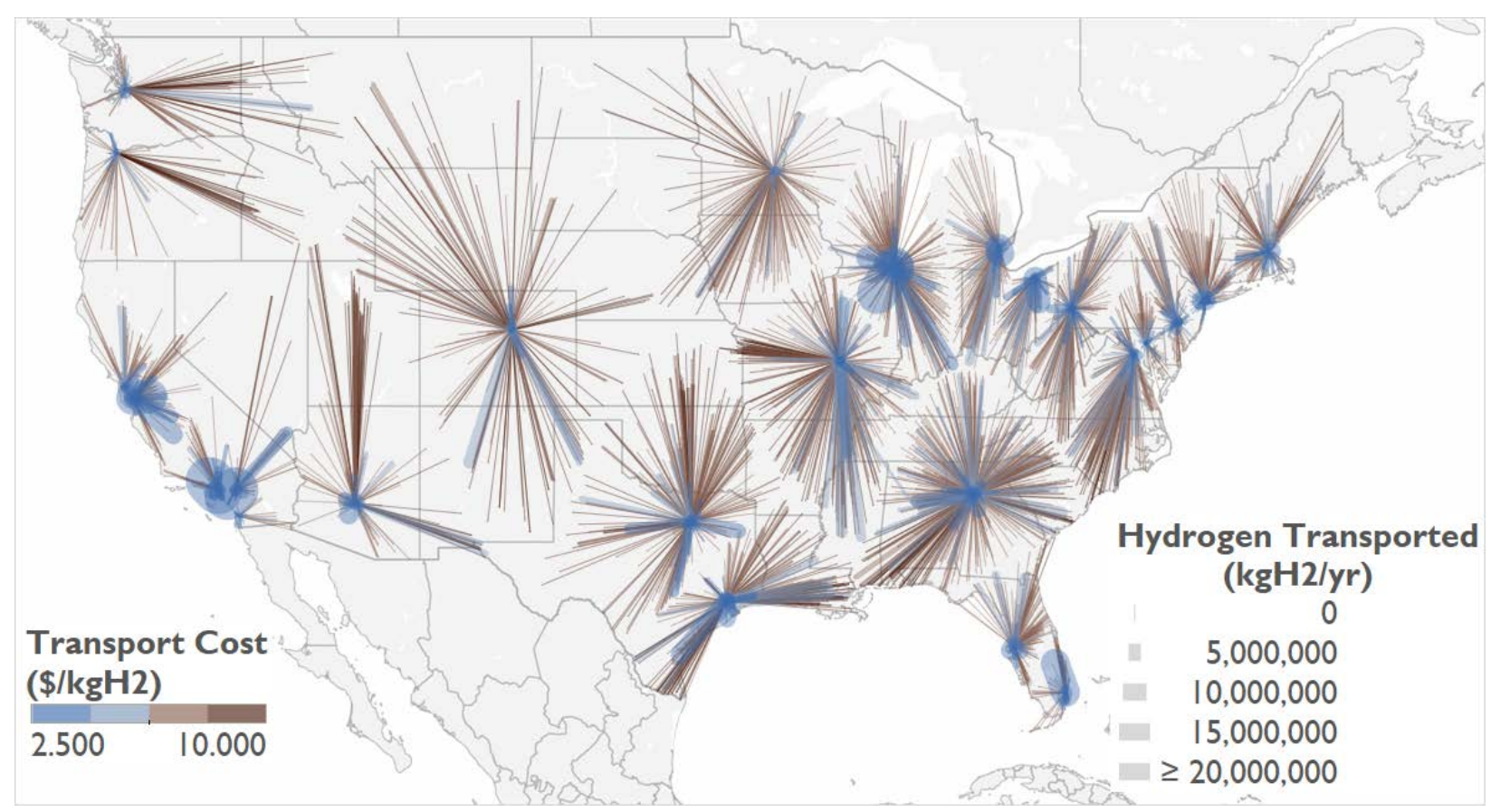

Figure 11. Cost of transporting hydrogen produced via SMR from landfills and WWTPs to the nearest large urban area

(Smaller and more distant sources incur higher transportation cost)

The biogas-derived hydrogen supply curves at these points of delivery ( 25 largest urban areas) are as shown in Figure 12. At a given cost, hydrogen availability is substantially lower than in Figure 10. The only exceptions are large cities which can avail themselves of hydrogen produced at nearby landfills (Figure 13, comparing combined production and delivery costs as supply curves for major urban areas). 


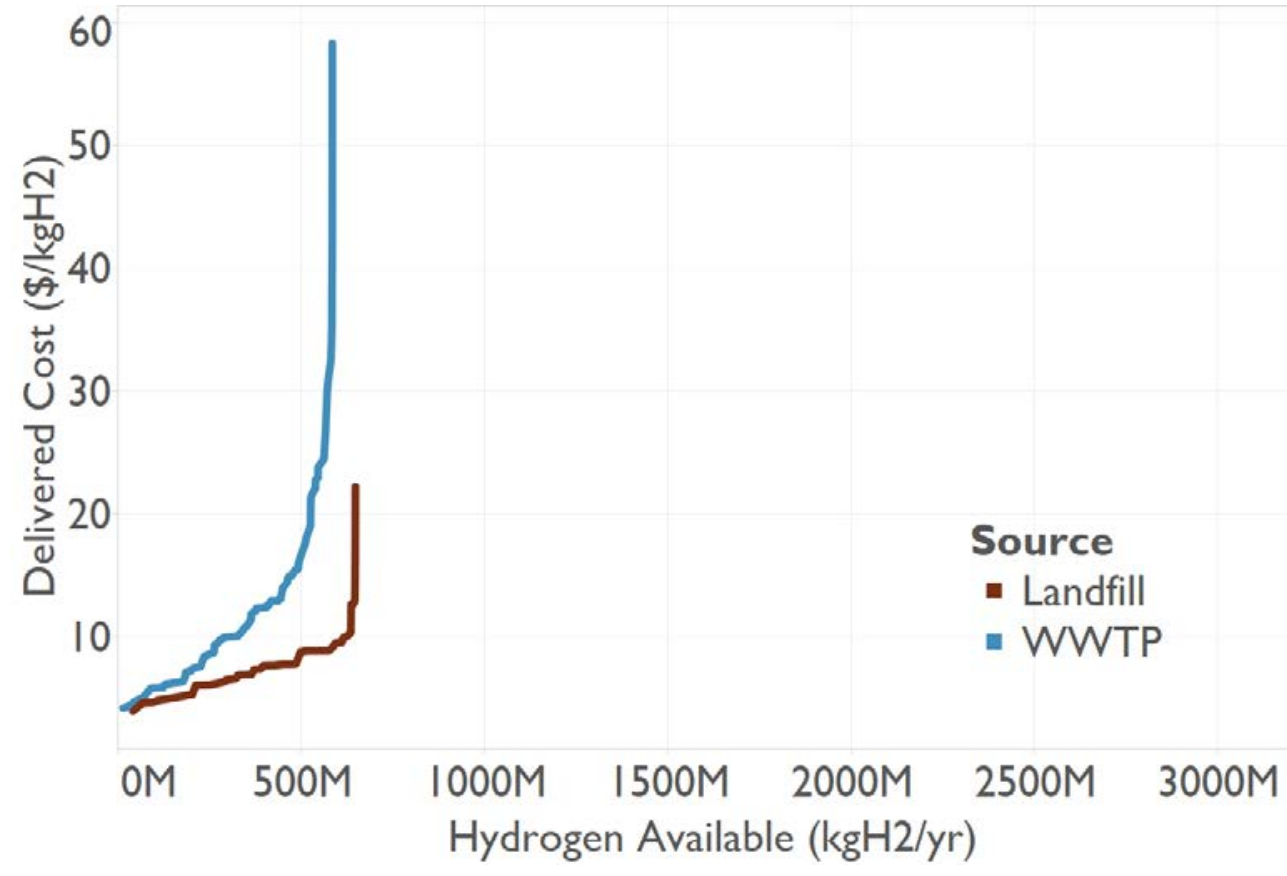

Figure 12. Supply curve for potential hydrogen production via SMR, delivered to the nearest large urban area, from biogas at landfills and WWTPs, using the lowest-cost delivery mode 


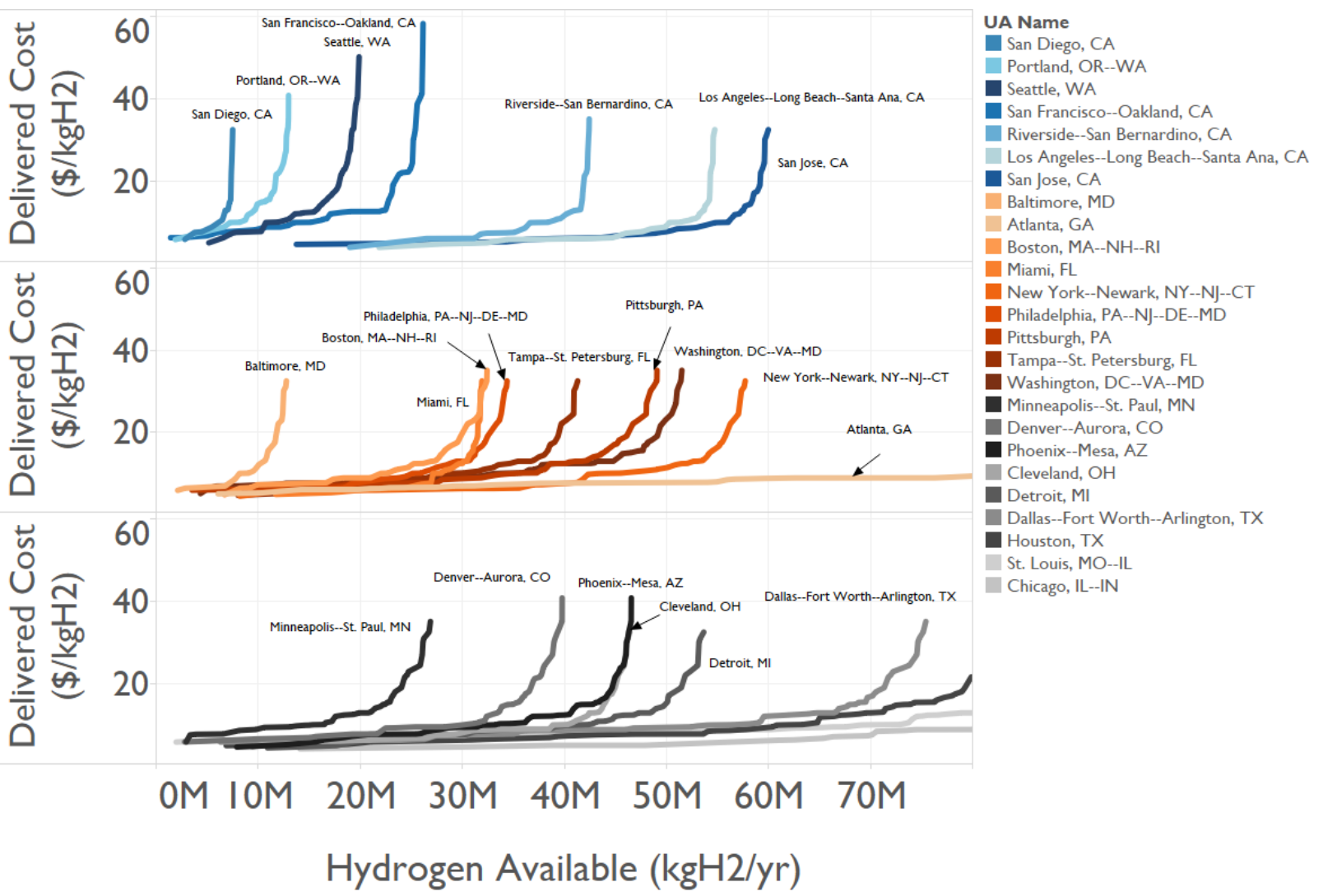

Figure 13. Supply curves for potential hydrogen production via SMR, delivered to the nearest large urban area, from biogas at landfills and WWTPs

\subsection{Hydrogen from Biomethane via Fuel Cells}

The estimation of hydrogen production via fuel cells follows the methodology in the previous section, except that the H2A fuel-cell-power model provides the cost of conversion from biogasto-hydrogen (Steward et al. 2013; U.S. DOE 2014). However, tri-generation (combined heat, hydrogen, and power [CHHP]) from molten carbonate systems are more complex than SMR systems in that the former can be tuned to adjust the output of electricity, heat, or hydrogen. For the purposes of this analysis, we assume an overall system efficiency of $65 \%$, where $80 \%$ of the system output appears in the form of hydrogen and the other $20 \%$ is in the form of heat and electricity (co-product sales are valued at the H2A default prices). It should be noted that a typical CHHP system usually operates at a significantly lower fraction of system output producing hydrogen, but for the purposes of this analysis, we consider a CHHP system that is operated toward maximizing its hydrogen output. This results in an overall conversion of each mmBtu of biomethane into $4.57 \mathrm{~kg}$ of hydrogen. Figure 14 illustrates the spatial pattern of fuelcell-based hydrogen, which is very similar to SMR in Figure 7 since both are based on the identical underlying resource.

The cost profiles from the detailed $\mathrm{H} 2 \mathrm{~A}$ fuel-cell-power model were first abstracted into a regression model, where the fuel cell system is assumed to cost $\$ 3,500 / \mathrm{kW}$ and the tariff for industrial electricity is $\$ 0.06 / \mathrm{kWh}$. Table 7 shows the resulting cost assumptions used in our geographic analysis. Because of the differing economies of scale, the CHHP costs are lower than SMR for sites with smaller biogas resource (producing approximately less than $175 \mathrm{~kg}$ of 
hydrogen per day), but higher for sites with larger resource. Figure 15 and Figure 16 display the cost distribution for fuel-cell-based hydrogen, for landfills and WWTPs, respectively, and Figure 17 through Figure 19 display the supply curves for production and delivery nationally, as well as city-specific delivery. It is evident that the fuel-cell-based hydrogen production has less overall resource at low cost than hydrogen produced via SMR and somewhat higher (by about $\$ 1.5 / \mathrm{kg}$ ) cost for that resource; this is due to the lower overall conversion rate for CHHP and the higher cost for CHHP conversion.

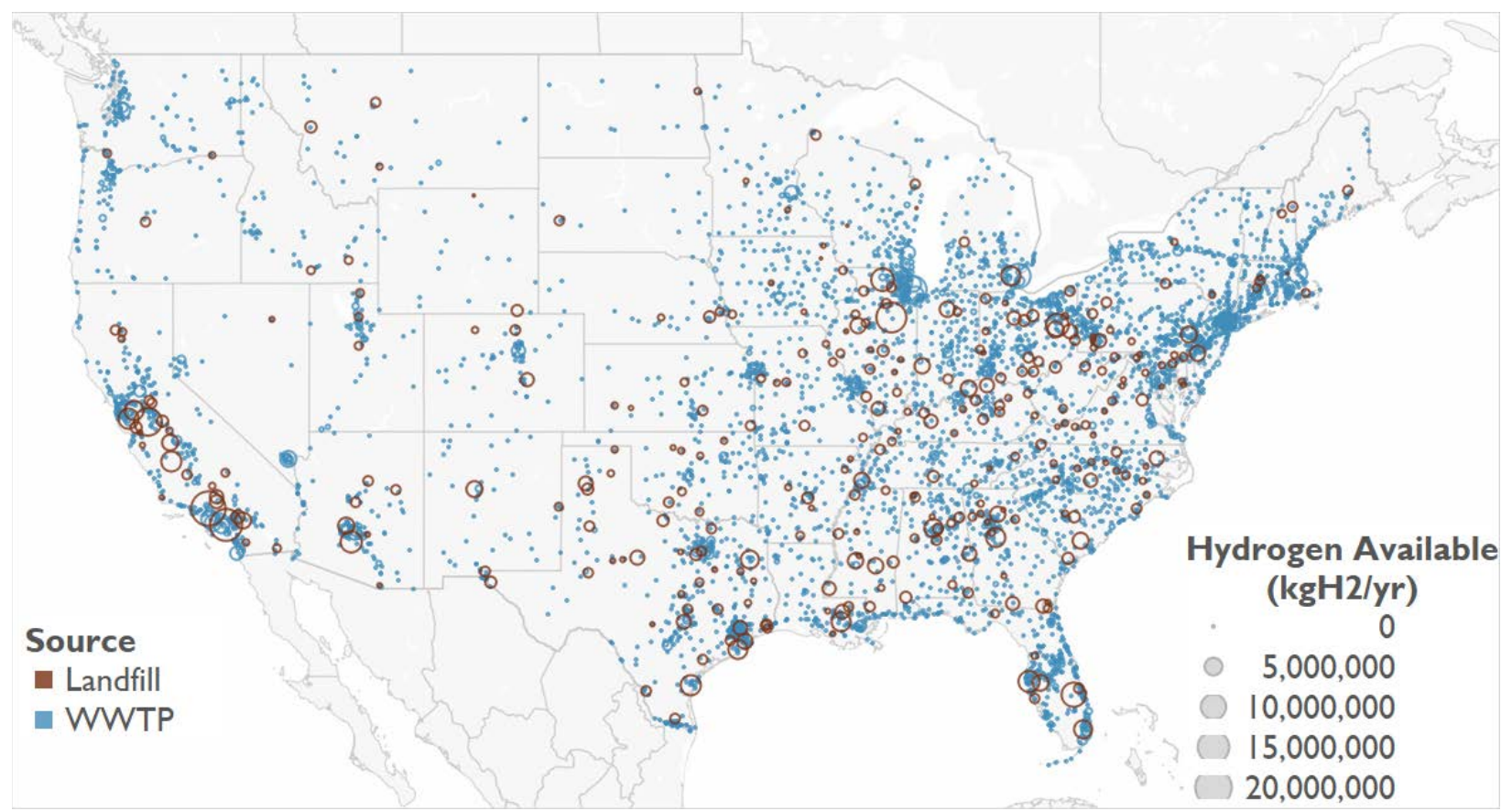

Figure 14. Potential hydrogen production via CHHP from biogas at landfills and WWTPs 
Table 7. Cost Assumptions for Hydrogen Production from Methane via CHHP

\begin{tabular}{|c|c|}
\hline Plant Capacity (kgH2/day) & Hydrogen Cost $\mathbf{( \$ \mathbf { k g H 2 } )}$ \\
\hline 50,000 & 5.99 \\
\hline 30,000 & 5.99 \\
\hline 20,000 & 5.99 \\
\hline 15,000 & 5.99 \\
\hline 10,000 & 5.99 \\
\hline 5,000 & 5.99 \\
\hline 3,000 & 5.99 \\
\hline 2,000 & 5.99 \\
\hline 1,500 & 5.99 \\
\hline 1,000 & 5.99 \\
\hline 500 & 5.99 \\
\hline 300 & 6.02 \\
\hline 200 & 6.47 \\
\hline 150 & 6.93 \\
\hline 100 & 7.77 \\
\hline 50 & 9.20 \\
\hline 30 & 9.98 \\
\hline
\end{tabular}

Source: Derived from Steward et al. 2013 and U.S. DOE 2014 (H2A Production Model)

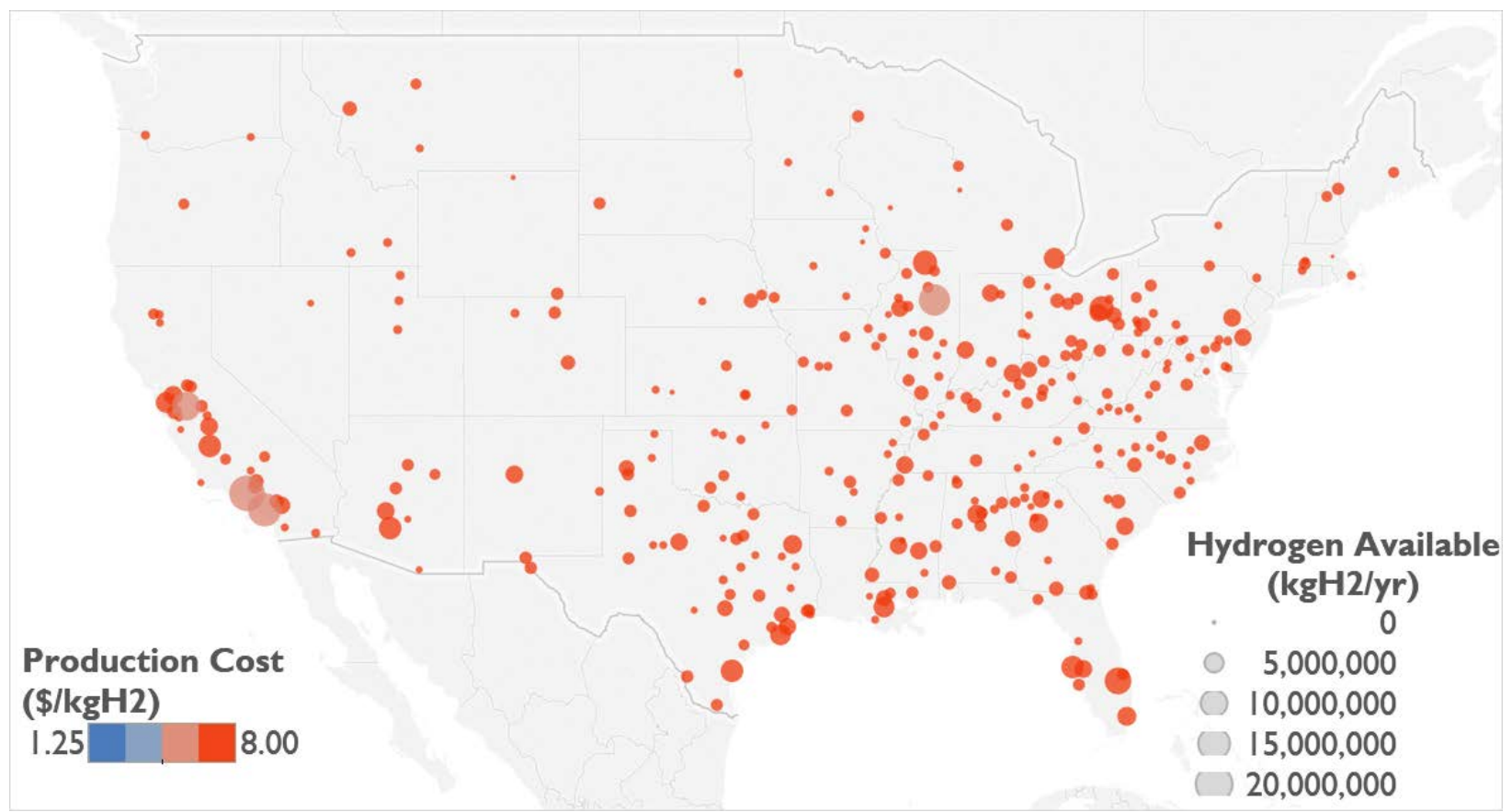

Figure 15. Estimated cost of hydrogen produced via CHHP from biogas at landfills 


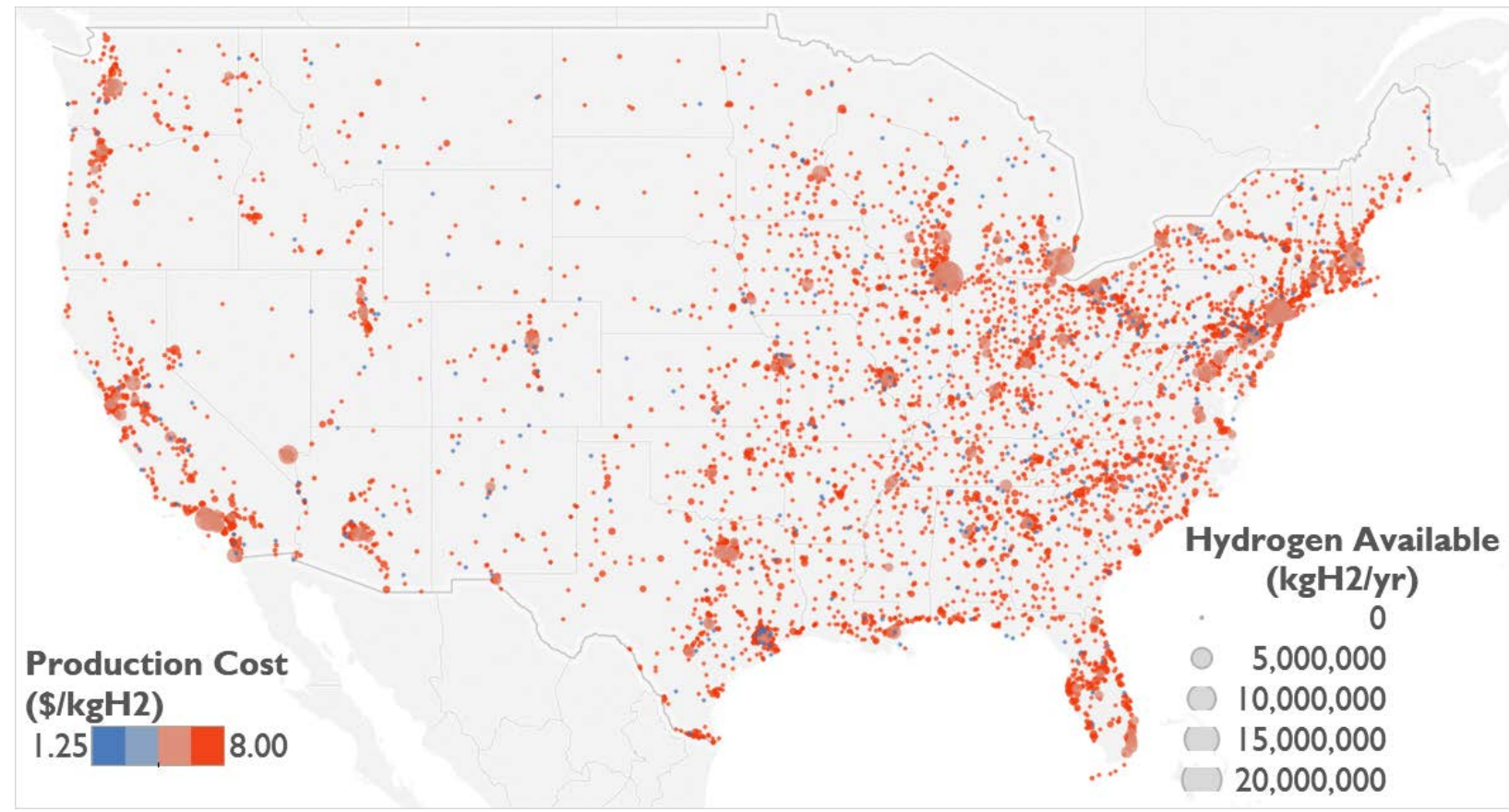

Figure 16. Estimated cost of hydrogen produced via CHHP from biogas at WWTPs

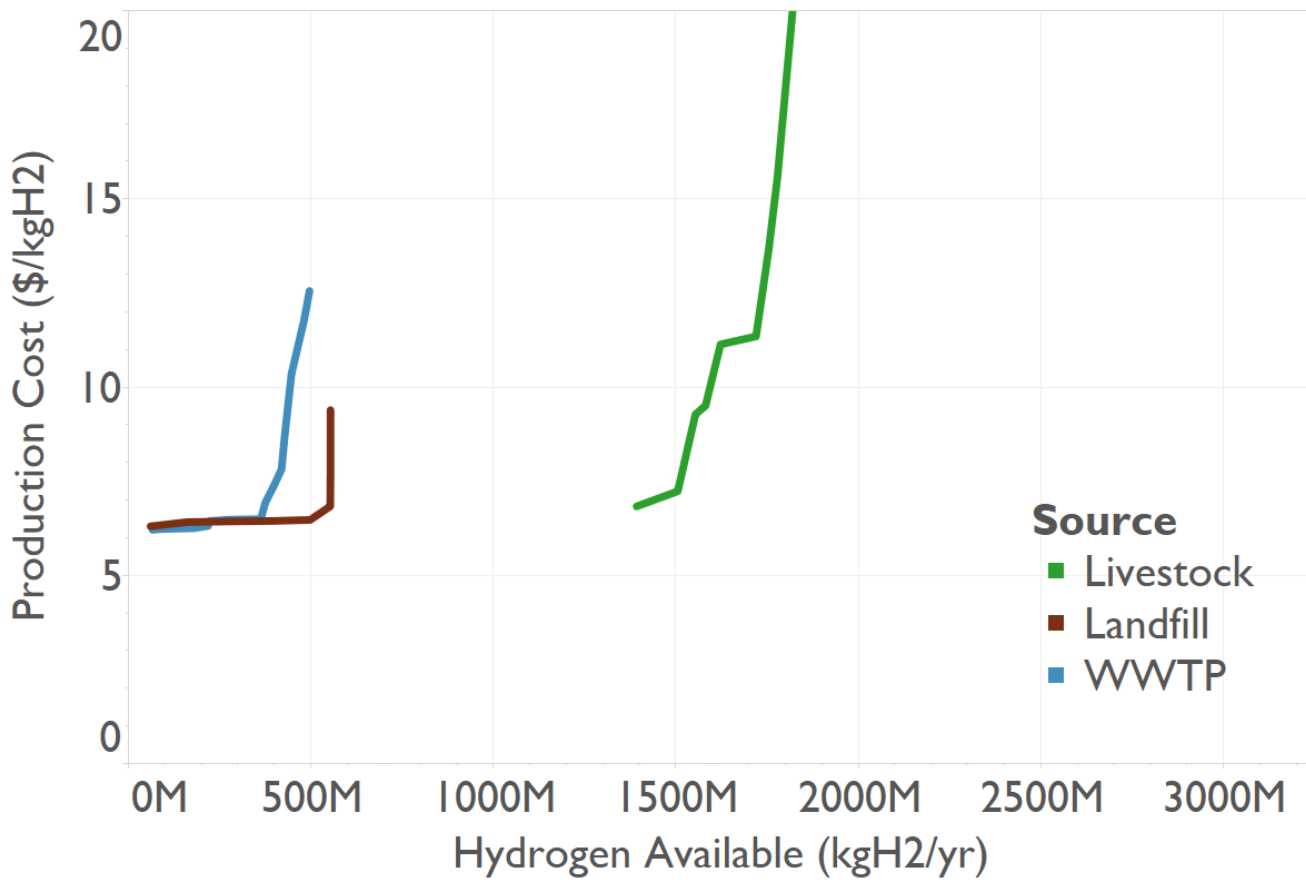

Figure 17. Supply curve for potential hydrogen production via CHHP from biogas at landfills, WWTPs, and livestock operations 


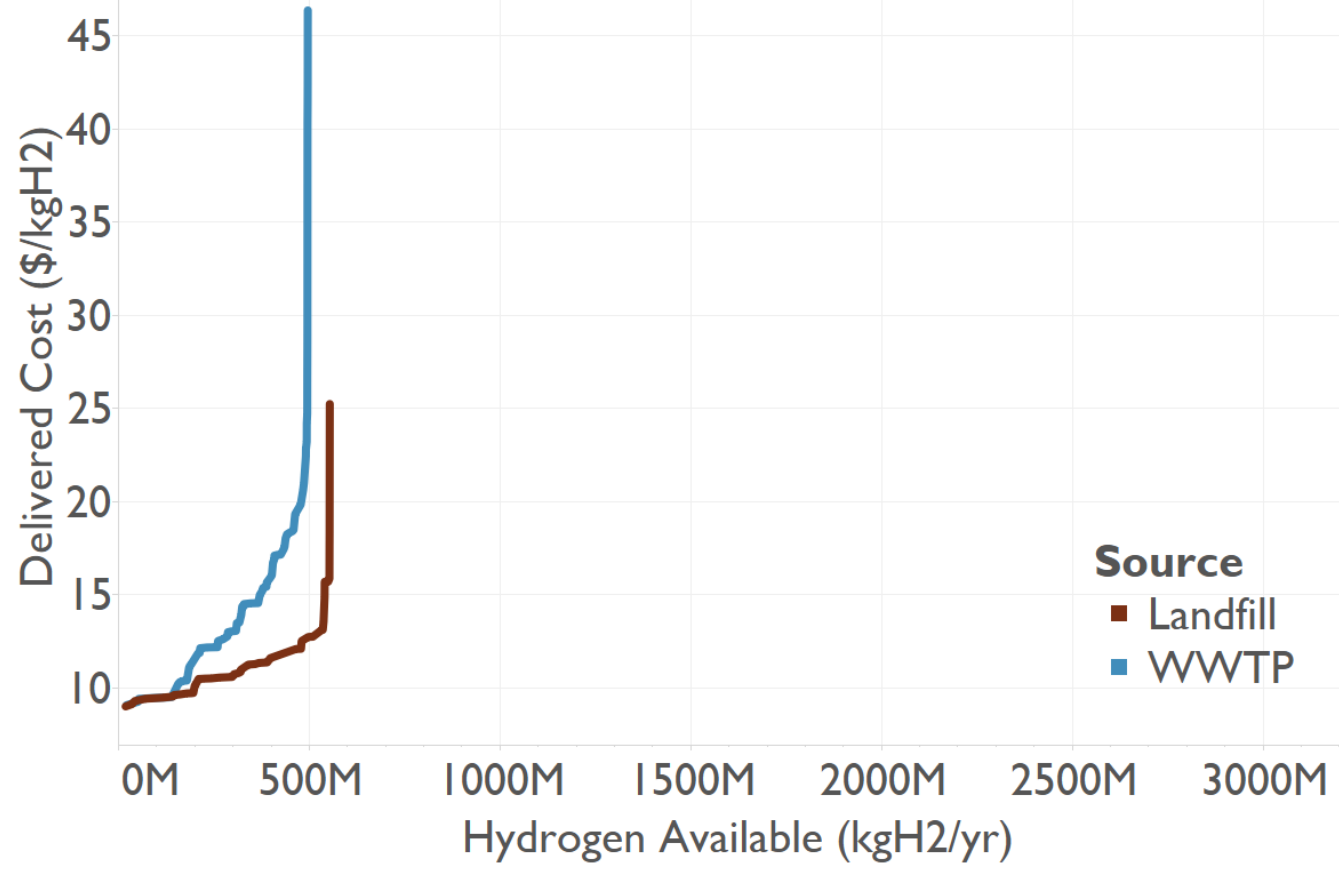

Figure 18. Supply curve for potential hydrogen production via CHHP, delivered to the nearest large urban area, from biogas at landfills and WWTPs 


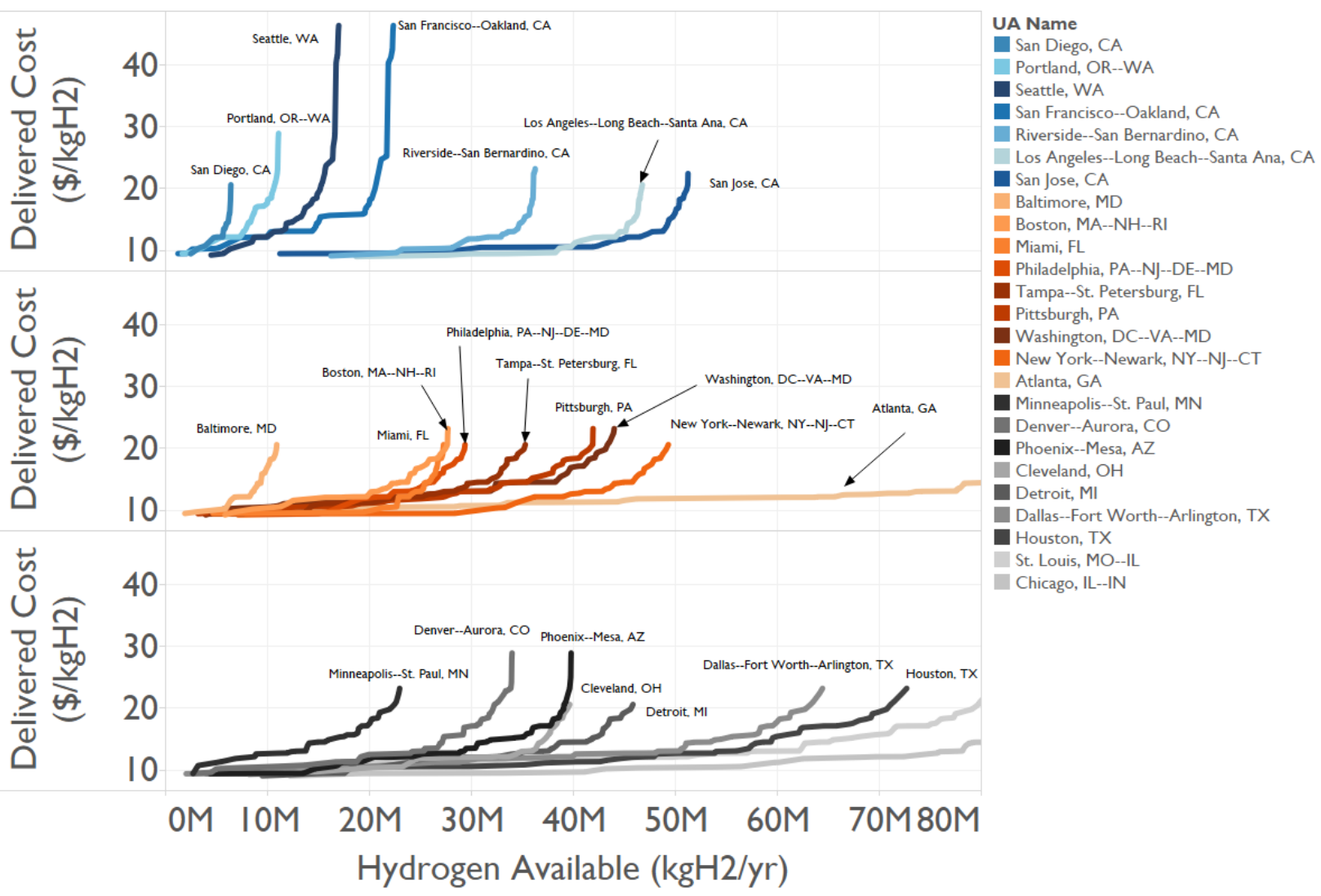

Figure 19. Supply curves for potential hydrogen production via CHHP, delivered to the nearest large urban area, from biogas at landfills and WWTPs

\subsection{Combined National Supply Curves for Hydrogen from Biomethane}

Figure 20 summarizes the estimate of SMR- and CHHP-based hydrogen from biogas. As mentioned previously, tri-generation yields a somewhat smaller hydrogen resource at a somewhat greater cost than does SMR, but it is important to remember that CHHP embodies considerably more flexible operation and potential economic benefits. The additional cost of delivering the resource from the point of production to the nearest large urban area typically increases the overall cost by several dollars per kilogram of hydrogen. 


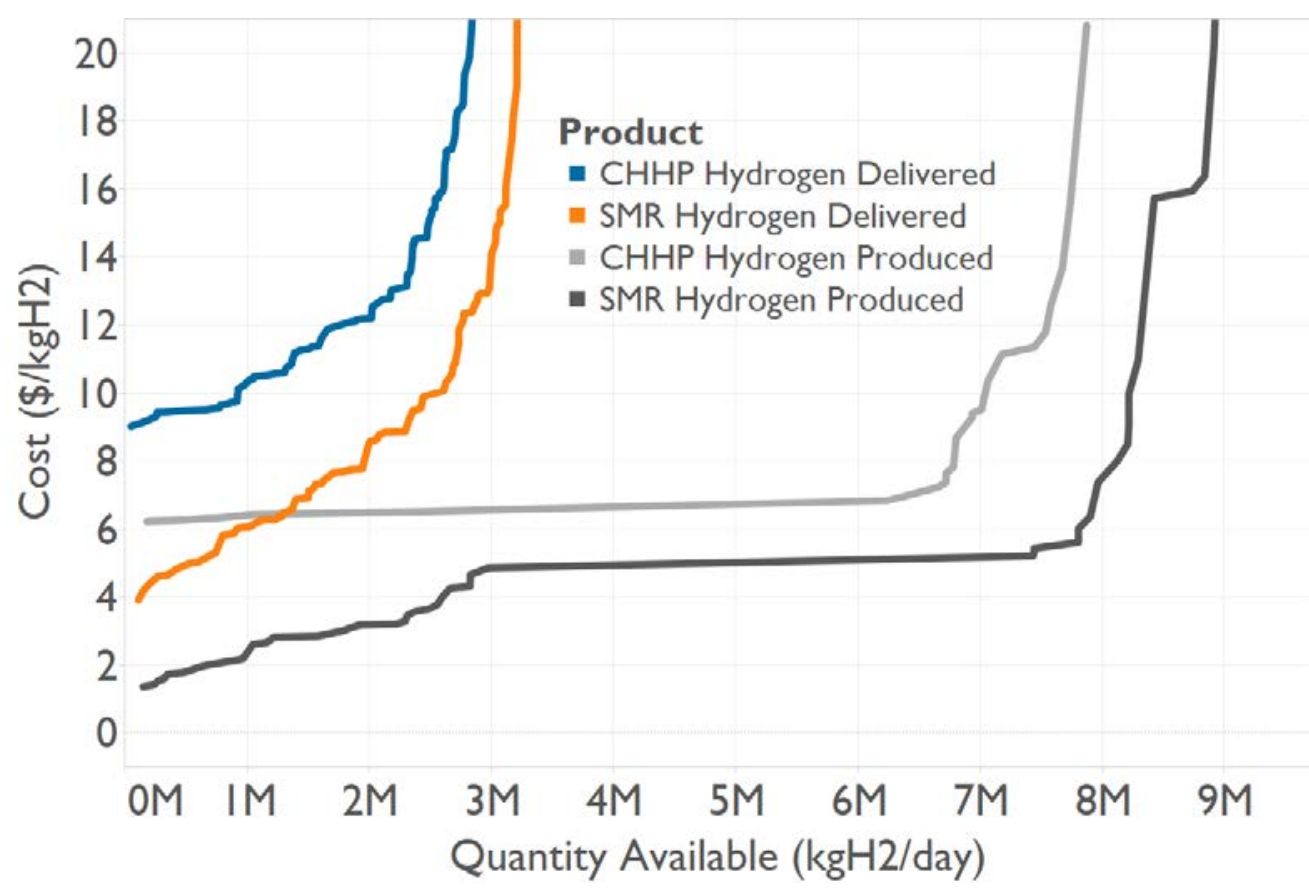

Figure 20. Supply curves for potential hydrogen from processing biogas at landfills, WWTPs, and livestock operations as produced, or from landfills and WWTPs delivered to the nearest large urban area

\subsection{Production Cost Comparison}

Typical costs for other hydrogen production pathways using future technologies generally lie in the $\$ 2-6 / \mathrm{kg}$ range (Figure 21), which is comparable to the production costs on the biogas cost curve up to about 7 million kg of hydrogen per day (Figure 20). Once delivery costs are accounted for, however, biogas-derived hydrogen only falls in that range when production is less than about 1 million kg of hydrogen per day, and only for SMR-derived hydrogen. The CHHP economies of scale are generally not favorable enough to produce significant quantities of hydrogen at less than $\$ 6$ per $\mathrm{kg}$ of hydrogen. However, more geographically detailed analysis, based on more accurate site-specific resource assessment, may reveal niche cases where biogasderived hydrogen can be produced and delivered at lower cost than other technologies. 


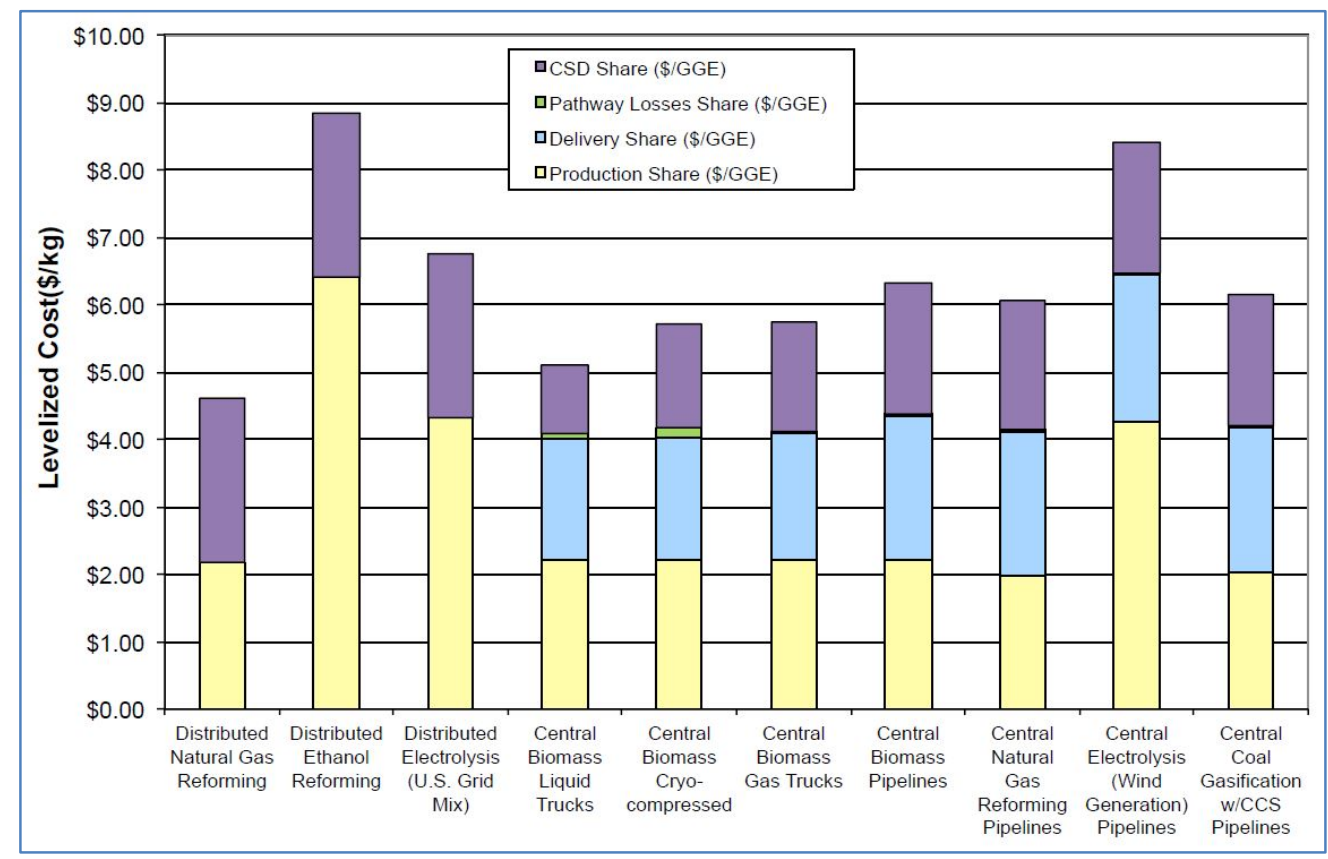

CSD - compression, storage, and dispensing; CCS - carbon capture and storage

Figure 21. Hydrogen production levelized costs for 10 pathways (excluding biogas)

Source: Ramsden et al. 2013 


\section{Discussion}

Supply curves uncertainty. The cost and quantity estimates in the foregoing sections are highly uncertain because they ignore the specific characteristics of individual biogas resource sites and because they rely on production and cost models that make simplifying assumptions. The most prominent sources of uncertainty are:

1. The assumption that anaerobic digesters could be present at particular WWTPs

2. Assumed efficiencies of the biogas production or cleanup technologies at landfills, WWTPs, and livestock operations

3. Economies of scale for SMR plants

4. Operating assumptions for CHHP systems

5. Techno-economic characteristics of SMR plants and CHHP systems

6. Willingness of facility owners to collect biogas and convert it to hydrogen, particularly since other uses of the biogas resource are more economical.

Biogas (and biomethane) estimates vary widely thus we consider our supply curves to be very preliminary. We used biomethane values for landfills and WWTP from Saur and Milbrandt (2014) because they are at a finer geographic resolution (point location) than the national level values in Murray et al. (2014) and thus allowing for a more detailed, site-specific analysis. Data for livestock operations is available at county level from Saur and Milbrandt (2014) but its structure did not have the attributes needed for the supply curve analysis (e.g. size of facility, number of animals, etc.) thus we used the national data from Murray et al. (2014) which has all attributes needed. While the biomethane estimates for WWTP are relatively close in both studies (481 billion BTU/day in Murray et al. (2014) and 338 billion BTU/day in Saur and Milbrandt (2014)), the biomethane estimates for landfills and livestock operations are very different. Saur and Milbrandt (2014) estimated about 1,528 billion BTU/day of biomethane from landfills while Murray et al. (2014) estimated about 2,146 billion BTU/day. Saur and Milbrandt (2014) estimated about 275 billion BTU/day of biomethane from livestock operations while Murray et al. (2014) estimated significantly more resource - about 5,489 billion BTU/day. The difference in the biomethane estimates is due to different data sources (national vs. county vs. site-specific) and methodology applied. Often, more resources are reported at national level (hence larger quantity in Murray et al. (2014)), less at state and county level (due to gaps in reporting), and even lesser amounts at point location (significant data gaps).

Overall, it is likely that the cost curves presented here could have at least a $50 \%$ uncertainty in quantity and a 50\% uncertainty in cost. Unfortunately, reducing these uncertainties would require a much higher-resolution inventory of potential biogas production sites and far more detailed site-specific inputs to cost models than are currently available.

Biogas production from crop residues and dedicated energy crops. As mentioned earlier, biogas can also be produced from crop residues and energy crops via "dry" fermentation and codigestion with other liquid waste material. However, due to limited technological and cost data, supply curves for these biogas-to-hydrogen production pathways were not included in this study. Below is a brief description of these processes. 
The dry fermentation process allows biogas production from organic matter with high dry matter content (up to $50 \%$ ) as opposed to the "wet" fermentation process of liquid material (e.g., animal manure and sewage sludge/biosolids containing sufficient water) used widely today. Dry fermentation is a relatively new method of biogas generation and thus, there are a small number of plants worldwide. Most of the plants are located in Germany, where commercially viable dry fermentation technology and processes have been developed and patented, but there are a few plants reported in Japan and Africa (Dryfermentation.com 2014). In November 2013, the world's largest dry fermentation facility and the first large-scale commercial facility of its kind in the United States opened near San Jose, California (Zero Waste Energy 2013). The facility will process an estimated 90,000 tons per year of commercial organic waste that would otherwise go to landfill, converting it to $1.6 \mathrm{MW}$ of renewable energy and 32,000 tons compost. The dry fermentation technology is receiving a lot of attention due to estimated higher biogas yield of crop residues and energy crops in comparison with animal manure. For example, corn stover is estimated to yield about $202 \mathrm{~m}^{3}$ of biogas per tonne of fresh matter $(\mathrm{t} \mathrm{FM})$ whereas biogas yield from cattle manure is about $45 \mathrm{~m}^{3} / \mathrm{t} \mathrm{FM}$ (Bassam 2010).

Co-digestion refers to the $\mathrm{AD}$ of multiple biodegradable substrates (feedstocks) in a digester system. Co-digestion can provide a better nutrient balance and therefore better digester performance and higher biogas yields (Wu 2007). Typically, sewage sludge and animal manure are used as the base substrate, which is mixed and digested together with small amounts of additional, higher-yielding substrate (e.g., food waste, FOG, crop residues) to maximize the biogas production. In addition to diverting food waste and FOG from landfills and public sewer lines, these high-energy materials have at least three times the methane (biogas) production potential than sewage sludge/biosolids and manure (EPA 2014). Increasingly, crop residues are fed together with animal manure in order to keep homogenous fermentation conditions and achieve higher biogas yield. 


\section{Conclusions}

Despite projected significant hydrogen potential from biogas, its utilization is yet to be fully realized. As of summer 2014, only one demo plant is producing hydrogen to power fuel cell vehicles. California is emerging as a key area in the biogas-to-hydrogen market. Not only does the state have the highest hydrogen potential from biogas, but it also has existing infrastructure and favorable policies to support further development of this industry.

Our cost and supply analysis of biogas-to-hydrogen production via SMR indicates that landfills and WWTPs dominate the low-cost supply of hydrogen, but that there is an appreciable amount of moderate-cost hydrogen from livestock operations. Tri-generation yields a somewhat smaller hydrogen resource at a somewhat greater cost than does SMR. It is expected that, as more fuel cells come online, their cost will go down, which will have a positive effect on the economics of tri-generation systems.

Regarding the market potential, our analysis suggests that at $\$ 5 / \mathrm{kg}$ (delivered cost) landfills can provide about 150 million $\mathrm{kg}$ of hydrogen per year and WWTPs can provide about 68 million $\mathrm{kg}$ of hydrogen per year. The annual amount of hydrogen that could be delivered at $\$ 10 / \mathrm{kg}$ grows to about 628 million $\mathrm{kg}$ from landfills and 326 million kg from WWTPs. To put this potential in perspective, the FCEV Emphasis scenario in a National Academies report (NRC 2013) projects hydrogen demand for FCEVs in 2030 at about 7.3 billion $\mathrm{kg}$ (equal to about $8 \%$ of fuel demand from the future US light duty vehicle fleet in that scenario) thus landfills and WWTPs can provide between $3 \%$ and $13 \%$ of that demand at $\$ 5 / \mathrm{kg}$ and $\$ 10 / \mathrm{kg}$ respectively. Livestock operations can provide additional hydrogen supply, as well as other biogas sources not examined here (e.g. crop residues).

Production costs of hydrogen from biogas are generally comparable with those of other hydrogen production pathways (e.g., natural gas SMR, coal gasification, biomass gasification, and wind electrolysis) in the $\$ 2-6 / \mathrm{kg}$ range. However, once delivery costs are accounted for, biogasderived hydrogen only falls in that range when production is less than about 1million $\mathrm{kg}$ of hydrogen per day, and only for SMR-derived hydrogen.

Despite the considerable uncertainty associated with the supply curve and production cost estimates, this study serves as a general reference and a placeholder until a more comprehensive study with much greater detail is completed. Future work could focus on the market potential for other biogas sources not included here (e.g. crop residues) or examine the biogas-to-hydrogen market potential in select regions to obtain detailed resource and cost data that could support indepth feasibility studies. 


\section{References}

Air Resources Board (ARB). 2014. Annual Evaluation of Fuel Cell Electric Vehicle Deployment and Hydrogen Fuel Station Network Development. Sacramento, CA: ARB. Accessed May 2015, http://www.arb.ca.gov/msprog/zevprog/ab8/ab8 report_final june2014.pdf.

ARB. 2013. "Manure Digesters in California." Sacramento, CA: ARB. Accessed April 2015, http://www.arb.ca.gov/ag/manuremgmt/operating-manure-digester-site-list-1st-quarter-2013.pdf.

Alternative Fuels Data Center. 2014. "Hydrogen.” Accessed July 2014, http://www.afdc.energy.gov/fuels/hydrogen.html.

Amon, R., M. Jenner, H. El-Mashad, R.Williams, and S. Kaffka. 2011. DRAFT report:

California's Food Processing Industry: Organic Residue Assessment. CEC PIER Contract 50008-017. Sacramento, CA: California Energy Commission.

Argonne National Laboratory (ANL). 2005. Hydrogen Demand, Production, and Cost by Region to 2050. ANL/ESD/05-2. Chicago, IL: ANL. Accessed July 2014, http://www.transportation.anl.gov/pdfs/TA/351.pdf.

Bush, B., O. Antonia, M. Melaina, D. Steward, J. Svede, and K. Webster. (2011). Summary of SERA Capabilities. Internal report. Golden, CO: NREL.

El Bassam, N. 2010. Handbook of Bioenergy Crops: A Complete Reference to Species, Development and Applications. $1^{\text {st }}$ ed. New York, NY: Earthscan/Taylor \& Francis.

Bush, B., M. Melaina, M. Penev, and W. Daniel. 2013. SERA Scenarios of Early Market Fuel Cell Electric Vehicle Introductions. Internal report. Golden, CO: NREL.

California Public Utilities Commission (CPUC). 2014. Order Instituting Rulemaking to Adopt Biomethane Standards and Requirements, Pipeline Open Access Rules, and Related Enforcement Provisions, R1302008- Proceeding. San Francisco, CA: CPUC. Accessed April 2015, http://delaps1.cpuc.ca.gov/CPUCProceedingLookup/f?p=401:56:6480450832515::NO.

Deublein, D., and A. Steinhauser. 2011. Biogas from Waste and Renewable Resources: An Introduction. $2^{\text {nd }}$ ed. Hoboken, NJ: John Wiley and Sons.

Dryfermentation.com. 2014. "Dry Fermentation: Biomass to Biogas.” Accessed November 2014, http://www.dryfermentation.com/index.html.

Environmental Protection Agency (EPA). 2011. "Market Opportunities for Biogas Recovery Systems at U.S. Livestock Facilities.” Washington, D.C.: EPA. Accessed December 2014, http://www.epa.gov/agstar/documents/biogas_recovery_systems_screenres.pdf.

EPA. 2014. "Organics: Anaerobic Digestion, Co-Digestion.” Washington, D.C.: Accessed November 2014, http://www.epa.gov/region9/organics/ad/codigest.html. 
Melaina, M., O. Antonia, and M. Penev. 2013. Blending Hydrogen into Natural Gas Pipeline Networks: A Review of Key Issues. NREL/TP-5600-51995. Golden, CO: NREL.

Murray, B.C., C.S. Galik, and T. Vegh. 2014. Biogas in the United States: An Assessment of Market Potential in a Carbon-Constrained Future. Nicholas Institute for Environmental Policy Solutions, Duke University. Accessed December 2014, http://nicholasinstitute.duke.edu/sites/default/files/publications/ni_r_14-02_full_pdf.pdf.

National Academy of Sciences. 2013. Transitions to Alternative Vehicles and Fuels. Washington, D.C.: National Academy of Sciences. Accessed December 2014, http://www.nap.edu/openbook.php?record_id=18264.

National Hydrogen Association. 2010. Hydrogen and Fuel Cells: The U.S. Market Report. Washington, D.C.: National Hydrogen Association. Accessed December 2014, http://www.innovatek.com/files/Hydrogen $\% 20$ and $\% 20$ fuel $\% 20$ cells.pdf.

National Research Council (NRC). 2013. "Transitions to Alternative Vehicles and Fuels." Committee on Transitions to Alternative Vehicles and Fuels; Board on Energy and Environmental Systems; Division on Engineering and Physical Sciences; National Research Council. National Academies Press, March 14, 2013. 170 pages.

OpenEI. "Scenario Evaluation, Regionalization \& Analysis (SERA).” Accessed September 2014, http://en.openei.org/wiki/Scenario_Evaluation,_Regionalization_\%26_Analysis_\%28SERA\%29.

Poeschl, M., S. Ward, and P. Owende. 2012. "Environmental impacts of biogas deployment Part II: life cycle assessment of multiple production and utilization pathways." Journal of Cleaner Production 24(0): 184-201.Accessed December 2014, http://dx.doi.org/10.1016/j.jclepro.2011.10.030.

Ramsden, T., M. Ruth, V. Diakov, M. Laffen, and T.A. Timbario. 2013. Hydrogen Pathways: Updated Cost, Well-to-Wheels Energy Use, and Emissions for the Current Technology Status of Ten Hydrogen Production, Delivery, and Distribution Scenarios. NREL/TP-6A10-60528. Golden, CO: NREL. Accessed December 2014, http:/www.nrel.gov/docs/fy14osti/60528.pdf.

Ryckebosch, E., M. Drouillon, and H. Veruaeren. 2011. "Techniques for transformation of biogas to biomethane." Biomass and Bioenergy 35(5): 1633-1645.

Saur, G., and A. Milbrandt. 2014. Renewable Hydrogen Potential from Biogas in the United States. NREL/TP-5400-60283. Golden, CO: NREL. Accessed December 2014, http://www.nrel.gov/docs/fy14osti/60283.pdf.

Saxena, R.C., D. Seal, S. Kumar, and H.B. Goyal. 2008. "Thermo-chemical routes for hydrogen rich gas from biomass: A review." Renewable and Sustainable Energy Reviews 12(7): 19091927. 
Steward, D., M. Penev, G. Saur, W. Becker, and J. Zuboy. 2013. Fuel Cell Power Model Version 2: Startup Guide, System Designs, and Case Studies. Modeling Electricity, Heat, and Hydrogen Generation from Fuel Cell-Based Distributed Energy Systems. NREL/TP-5600-57457. Golden, CO: NREL. Accessed December 2014, http://www.nrel.gov/docs/fy13osti/57457.pdf.

U.S. Department of Energy (U.S. DOE). 2011. "Energy Department Applauds World's First Fuel Cell and Hydrogen Energy Station in Orange County." Washington, D.C.: DOE. Accessed September 2014, http://energy.gov/articles/energy-department-applauds-world-s-first-fuel-celland-hydrogen-energy-station-orange.

U.S. DOE. 2014. "DOE H2A Production Analysis Case Studies." H2A Central and Forecourt SMR Spreadsheets, version 3.1. Washington, D.C.: DOE. Accessed December 2014, http://www.hydrogen.energy.gov/h2a prod_studies.html.

Vegh, T. (April 7, 2014). Nicholas Institute for Environmental Policy Solutions, Duke University. Private communication via e-mail.

Wu, W. 2007. Anaerobic co-digestion of biomass for methane production: recent research achievements. Ames, IA: Iowa State University. Accessed November 2014, home.eng.iastate.edu/ tge/ce421-521/wei.pdf.

Zero Waste Energy. 2013. "Largest Dry Fermentation Anaerobic Digestion Facility in the World Opens." Lafayette, CA: Zero Waste Energy. Accessed July 2014, http://zerowasteenergy.com/worlds-largest-dry-fermentation-anaerobic-digestion-facility-opens/. 